San Jose State University

SJSU ScholarWorks

Master's Theses

Master's Theses and Graduate Research

2002

\title{
Evaluation of preparticipation forms for high schools and community colleges
}

Matthew Smith

San Jose State University

Follow this and additional works at: https://scholarworks.sjsu.edu/etd_theses

\section{Recommended Citation}

Smith, Matthew, "Evaluation of preparticipation forms for high schools and community colleges" (2002). Master's Theses. 2376.

DOI: https://doi.org/10.31979/etd.bf2u-8jxf

https://scholarworks.sjsu.edu/etd_theses/2376

This Thesis is brought to you for free and open access by the Master's Theses and Graduate Research at SJSU ScholarWorks. It has been accepted for inclusion in Master's Theses by an authorized administrator of SJSU ScholarWorks. For more information, please contact scholarworks@sjsu.edu. 


\section{INFORMATION TO USERS}

This manuscript has been reproduced from the microfilm master. UMI films the text directly from the original or copy submitted. Thus, some thesis and dissertation copies are in typewriter face, while others may be from any type of computer printer.

The quality of this reproduction is dependent upon the quality of the copy submitted. Broken or indistinct print, colored or poor quality illustrations and photographs, print bleedthrough, substandard margins, and improper alignment can adversely affect reproduction.

In the unlikely event that the author did not send UMI a complete manuscript and there are missing pages, these will be noted. Also, if unauthorized copyright material had to be removed, a note will indicate the deletion.

Oversize materials (e.g., maps, drawings, charts) are reproduced by sectioning the original, beginning at the upper left-hand corner and continuing from left to right in equal sections with small overlaps.

ProQuest Information and Leaming 300 North Zeeb Road, Ann Arbor, Mi 48106-1346 USA 800-521-0600

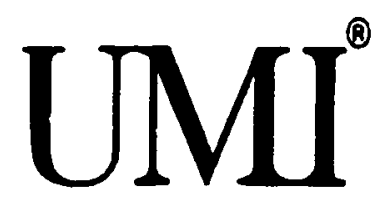



EVALUATION OF PREPARTICIPATION FORMS FOR HIGH SCHOOLS AND COMMUNITY COLLEGES

\author{
A Thesis \\ Presented to \\ The Faculty of the Department of Human Performance \\ San Jose State University \\ In Partial Fulfillment \\ of the Requirements for the Degree \\ Master of Arts
}

by

Matthew Smith

December 2002 
UMI Number: 1411629

Copyright 2002 by

Smith, Matthew W. H.

All rights reserved.

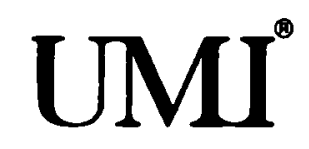

UMI Microform 1411629

Copyright 2003 by ProQuest Information and Learning Company. All rights reserved. This microform edition is protected against unauthorized copying under Title 17, United States Code.

ProQuest Information and Learning Company 300 North Zeeb Road

P.O. Box 1346

Ann Arbor, MI 48106-1346 
(C) 2002

Matthew W. H. Smith

ALL RIGHTS RESERVED 
APPROVED FOR THE DEPARTMENT OF HUMAN PERFORMANCE

envt

Emily H. Wughalter, Ed.D., Chair

San Jose State University, Department of Human Performance

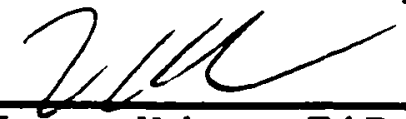

Leamor Kahanov, Ed.D, ATC

San Jose State University, Department of Human Performance

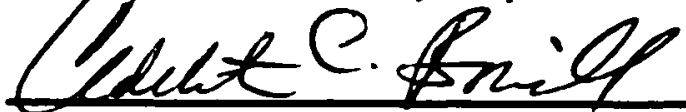

Adelita C. Bonilla, ATC

Burlingame High School

Sports Therapy Associates

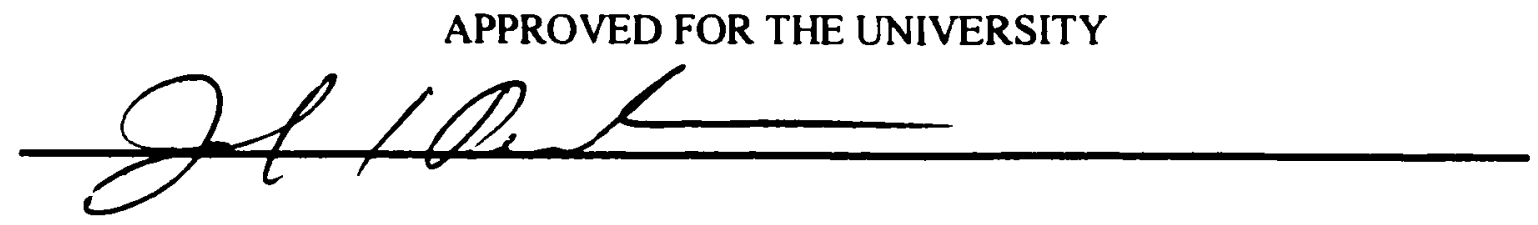




\title{
ABSTRACT \\ PRE-PARTICIPATION EVALUATION FORMS FOR HIGH SCHOOLS AND COMMUNITY COLLEGES
}

\author{
by Matthew W. H. Smith
}

This study examined the content of preparticipation physical evaluation (PPE)

forms used in high schools and community colleges in the Bay Area. Letters were mailed to athletic directors requesting a copy of the PPE form used at their institution along with their answers to a short survey. The collected forms were descriptively analyzed for content to determine if the PPE forms contained necessary and pertinent components of the preparticipation evaluation, specifically: demographic questions, cardiac abnormalities, head injuries, medications, orthopaedic problems/previous injury, environmental conditions, gynecological questions, and immunizations. From the collected PPE forms it appeared that high schools needed improvement on their PPE forms versus the community colleges. In almost half ( $46 \%$ ) of the high schools that returned a PPE form there was little information gathered about the athlete beyond the demographic questions. 


\section{DEDICATION}

I dedicate this project to my parents who have encouraged me to follow my dreams and supported me on my journey through graduate school. I also dedicate this project to Patrick FitzGerald who gave me an opportunity to work in athletics and inspired my commitment to the profession of athletic training. 


\section{ACKNOWLEDGEMENTS}

The award of a Master's Degree is given to one individual, but behind that individual is a host of others who contribute to the success of the degree by lending their support. To the many people who contributed to this thesis I give my deepest and heart felt thanks.

Specifically I would like to thank my thesis committee members. Dr. Emily Wughalter, whose expertise, guidance, and encouragement helped focus my thesis to become the document that you now read. Dr. Leamor Kahanov, whose experience in athletic training helped direct my thesis towards its final outcome. Ms. Addie Bonilla, provided friendship, encouragement, and support on the journey to complete the thesis. 


\section{Table of Contents}

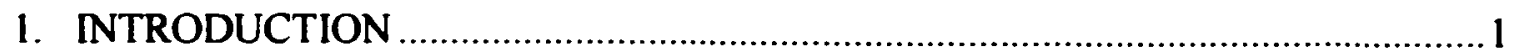

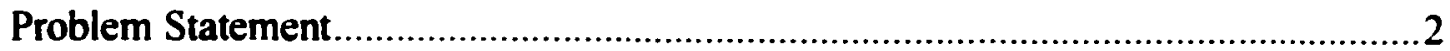

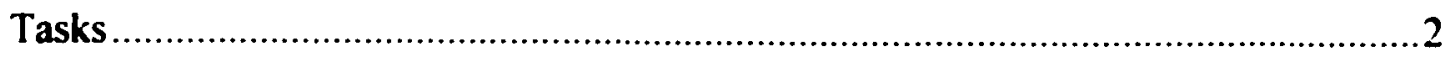

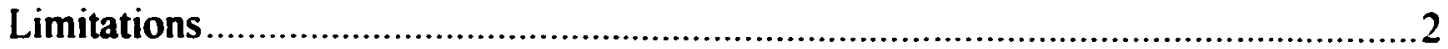

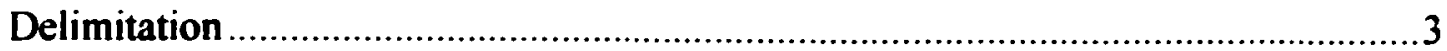

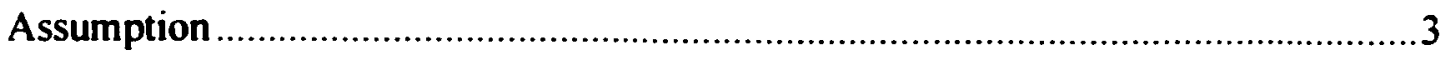

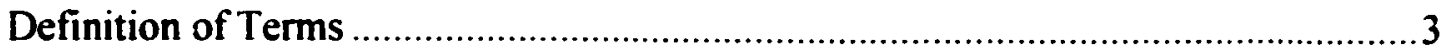

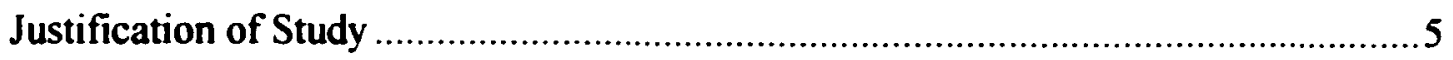

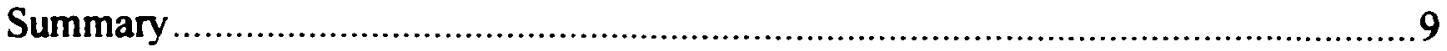

2. REVIEW OF LITERATURE .................................................................. 11

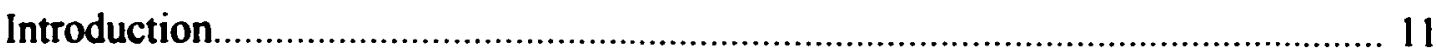

Use of the Preparticipation Physical Evaluation ............................................. 11

Purpose of the Preparticipation Physical Evaluation.......................................... 15

Aspects of the Preparticipation Physical Evaluation ......................................... 17

Parents`/Athletes`Knowledge/View of the Preparticipation Physical

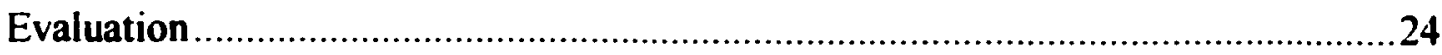

Legal Aspects of the Preparticipation Physical Evaluation....................................25

Recommendations from the American Heart Association .................................. 27

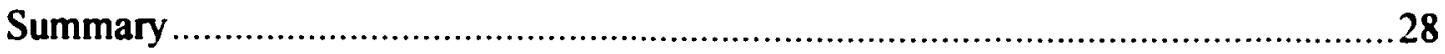

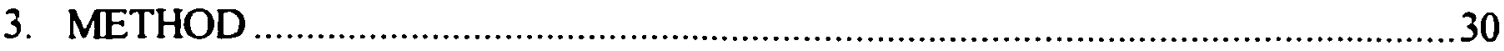

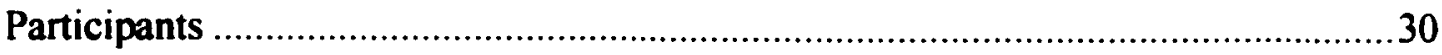




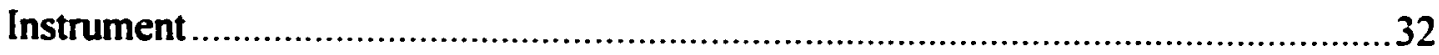

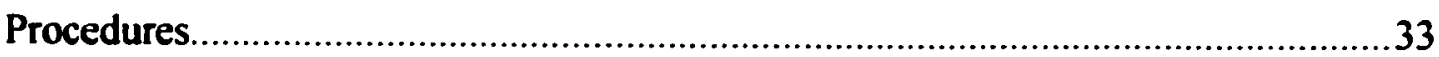

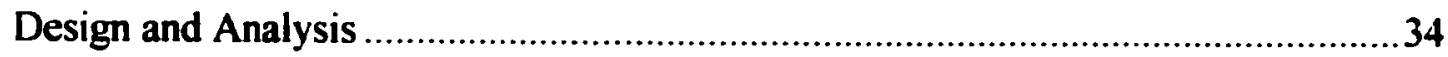

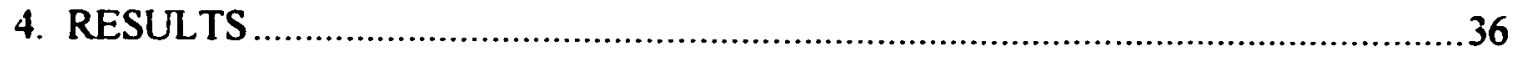

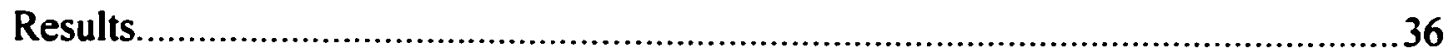

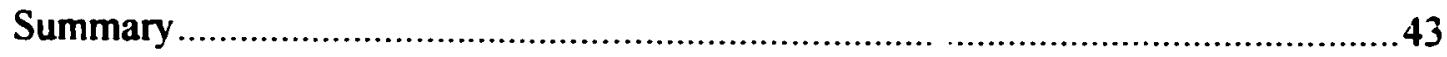

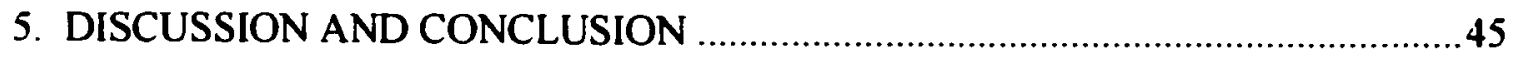

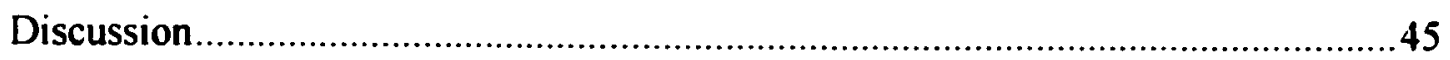

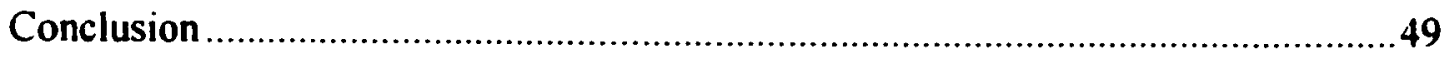

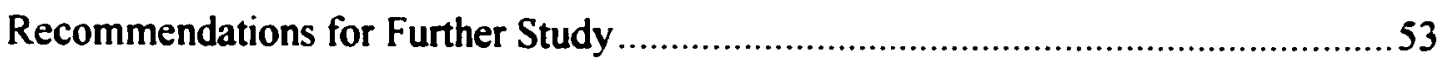

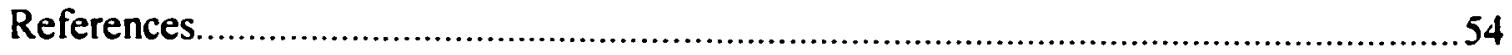

Appendix A Letter to Athletic Directors ...........................................................58

Appendix B Preparticipation Physical Evaluation Survey .......................................61

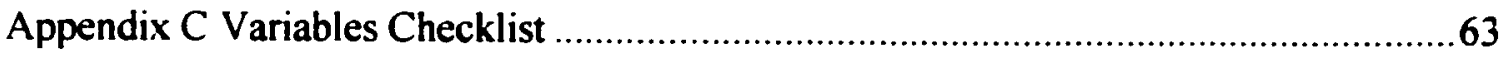

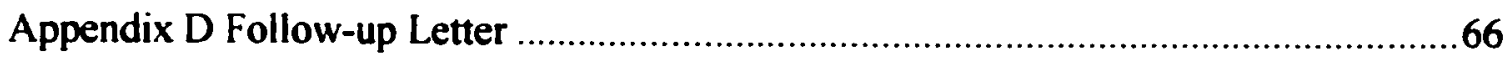

Appendix E Variables Checklist with Data ...........................................................68

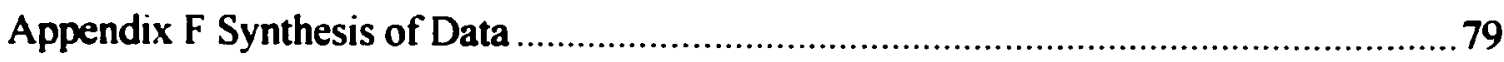

Appendix G Approval Letter From San Jose State University

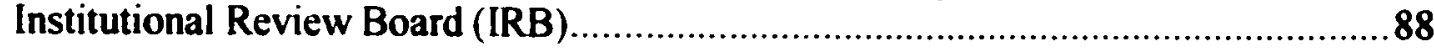




\section{Chapter 1}

\section{INTRODUCTION}

Each year millions of high school students participate in athletics (Glover, Marion, \& Matheson, 1999). Prior to athletic participation athletes must be medically cleared to play. Thus, each year, athletes should be evaluated for sport participation using a preparticipation physical evaluation (PPE). In this paper current PPE forms used at high schools in Santa Clara County and community colleges in the San Francisco Bay Area were examined. Each PPE form was examined to descriptively analyze if an athlete`s history such as cardiac, musculoskeletal, exercise-induced asthma, neurological injury, heat-related illness, harmful health habits, and general health screening is measured by the PPE's used.

As reported by Feinstein, Soileau, and Daniel (1988) and Tanji (1990), an annual physical exam is required in 35 states to determine an athlete's eligibility to participate in sports; however no uniform form is used requiring a yearly exam for sport participation. Hoekelman (1992) mentioned that an important aspect of sport participation is to be able to do so without risk of injury due to prior medical conditions. PPEs are used to help identify prior medical conditions and address them so an athlete can participate with minimal risk.

Athletes are examined by numerous physicians during the course of a school year and physicians complete many different medical history forms. According to Feinstein, Soileau, and Daniel (1988) some of these medical history forms contain extensive 
information while other forms contain minimal information. Currently no uniform form is used even within the same state.

\section{Problem Statement}

The purpose of this study was to descriptively analyze various medical history and physical exam forms used in high schools and community colleges to evaluate students prior to athletic participation and to inform individuals about what is being used so they can make a more informed decision about the PPE form currently used at the respective educational institution.

Tasks

The following tasks were accomplished through the conduct of the study:

1. PPE forms used by Santa Clara County high schools and San Francisco Bay area community colleges were collected.

2. PPE forms were descriptively analyzed for content on cardiac abnormalities, head injuries, medications, orthopaedic problems, previous injuries, environmental conditions, gynecological questions, immunizations, and demographic questions such as name, age, sex, grade level, phone number, and address.

3. Results were synthesized and provided to participating Santa Clara County high schools and San Francisco Bay area community colleges.

\section{Limitations}

1. The response rate may be a limitation of the study. Those schools declining to return the PPE may have done so due to the lack of a PPE form.

2. Individuals who completed the survey were not known to the investigator. 
3. Athletic trainers were not present at all of the high schools surveyed. Therefore, an individual who may not be familiar with the school's policy may have answered the survey questions.

\section{Delimitation}

Data were collected from high schools of Santa Clara County and San Francisco Bay area Community Colleges. Generalizability may not extend beyond this locale.

\section{Assumption}

The assumption made for this study was that each school would have some form of a PPE, but the form lengths and content would vary from school to school.

\section{Definition of Terms}

Annual Physical Exam. An annual physical examination is performed by a physician, conducted on a yearly basis.

Cardiac Abnormalities. Cardiac abnormalities are defined as deviations from a normal heart rhythm.

Community College Athlete. A community college athlete is defined as any community college student who participates in one or more of the numerous sports offered by a two-year associate degree school.

Environmental conditions. Environmental conditions are those conditions related to heat, cold, wind, and rain that affect an athlete's ability to participate fully in sport.

Head injuries. A head injury is defined as any injury that the athlete sustains that results in a headache, dizziness, blurred vision, ringing in the ears, nausea, vomiting, or unconsciousness. 
High School Athlete. A secondary school athlete is defined as any high school student who participates in one or more of the numerous sports offered by a secondary school.

Immunizations. Immunizations are shots an athlete receives for preventing diseases such as tetanus, Hepatitus B, measles, and chicken pox.

Medications. A medication is defined as any substance ingested by an athlete to help relieve pain and/or swelling.

Musculoskeletal Exam. In Stedman's Medical Dictionary (Stedman’s Medical Dictionary, $25^{\text {th }}$ edition, 1990 ) musculoskeletal examination relates to the muscles and to the skeleton. The musculoskeletal exam is the portion of the physical evaluation, through muscle testing, which determines the strength of an individual's muscles. The musculoskeletal evaluation also measures the stability and/or laxity and range of motion of an individual's joints.

Orthopaedic problems. Orthopaedic problems are related to the muscles, tendons, and ligaments of the body.

Preparticipation Physical Evaluation (PPE). The preparticipation physical evaluation is a battery of tests and medical history questions that a student-athlete must complete prior to participation in athletics. The exam is usually completed once a year and is performed by an athlete's personal physician or the team doctor for the school.

Previous injuries. Previous injuries are defined as any injury an athlete had sustained prior to the physical evaluation. 


\section{Justification of the Study}

Results of the current study will help to determine the use and/or detail of PPE forms used in Santa Clara high schools and San Francisco Bay area community colleges during preparticipation evaluations. California does not provide state regulations specifying head injuries, medications, orthopaedic problems, previous injuries, environmental conditions, gynecological issues, immunizations, and demographic questions such as age, sex, phone number, and address or how often the PPE should be conducted. No uniform form is currently used for the PPE and therefore some important aspects of the PPE may be missed. The content of currently used PPE forms was examined to determine if they contain pertinent components of the PPE such as cardiac abnormalities, head injuries, medications, orthopaedic problems, and previous injuries. The compilation of results sent to the schools may contribute to more uniform preparticipation physicals so that a complete medical history is taken and an increase in prevention of injuries and in the quality of the health care can be provided to athletes.

Physical evaluations are important to athletic trainers so that preexisting conditions can be identified. Possible restrictions may be required and a physical evaluation may prevent further injury to athletes. An example of the importance of a PPE is as in the case of an athlete who might have had one or more concussions in the past. Treatment of the concussion does not change, but the time frame in which an athlete is allowed to safely return to play changes depending on the number and severity of concussions an athlete has had. If an athlete is allowed to return to play prematurely there is the increased susceptibility to injury from contact and the possibility of death. 
Another example is an athlete with a heart condition. If left undetected an athlete may have no problem, but may also die from sudden cardiac death. If an athlete's medical history is unknown an athlete may risk death during practice or competition. Gathering knowledge of an athlete's medical history and conducting a physical evaluation may prevent this situation.

Currently no uniform PPE form is used in high school or community college athletics. According to Ball (1991) multiple health history and physical forms exist, including both adult and pediatric, which are not appropriate for sports screening. Tanji (1990) also mentioned that no uniform PPE form exists for the medical history and physical evaluation. Many PPE forms are used and range from a few questions to two pages. Some examples of the various PPE forms that are used can be found in Tanji (1990), Koester (1995), Lyznicki, Nielsen, and Schneider (2000), Fields (1994), and American Academy of Family Physicians, American Academy of Pediatrics, American Medical Society for Sports Medicine, American Orthopaedic Society for Sports Medicine and the American Osteopathic Society of Sports Medicine (1997). A form was published in 1996 in monograph form in The Physician and Sportsmedicine and is endorsed by the American Academy of Family Physicians, American Academy of Pediatrics, American Medical Society for Sports Medicine, American Orthopaedic Society for Sports Medicine and the American Osteopathic Society of Sports Medicine (1997). Their form outlines the various aspects of the preparticipation evaluation. The aspects evaluated are medical or musculoskeletal conditions that may cause injury/illness during competition, detecting possible life-threatening or debilitating medical or musculoskeletal conditions, addressing 
legal or insurance issues, determining the health of the athlete, counseling the athlete, and assessing fitness level for specific sports. A comprehensive medical history is provided in the monograph for physicians to use during preparticipation evaluations of athletes. Though this form is endorsed by five major medical societies it is not uniformly used.

A critical review of the monograph form reveals repetition of questions that could be restated as one question. A question about vitamin or supplement uses only queries about the past with no mention of vitamin or supplement use in the present. It is important to know if an athlete uses any performance enhancement drugs so that the physician and/or athletic trainer may be aware should the athlete have any side effects related to the drug. The vitamin/supplement question could be rephrased to include both past and present use of supplements or vitamins. The form surveys whether an individual wants to weigh more or less than they do now as a yes/no question. One important item that is missing from the PPE form in the monograph is a question regarding whether or not an athlete is missing any one of a paired organ (e.g., eye, kidney, or testicle) (American Academy of Family Physicians et al., 1997). If an athlete has only one of a paired organ he or she may be restricted from playing contact sports because of the possibility of injury to the one remaining organ. Arnheim and Prentice (2000) suggested that pregnant females may continue to play sports up through the third month of pregnancy and can be continued until the seventh month if no complications arise. Arnheim and Prentice noted that females usually discontinue sport participation after the third month due to a drop in their performance. Arnheim and Prentice (2000) stated "pregnancy induced hypertension, preterm rupture of membranes, preterm labor during 
the prior or current pregnancy or both, incompetent cervix or cerclage, persistent secondor third-trimester bleeding, and intrauterine growth retardation" as contraindications for sport participation (Arnheim \& Prentice, p. 866). Female athletes should to be queried about pregnancy. Pregnant athletes should not participate in contact/collision sports until they are cleared by their physician (American Academy of Family Physicians et al., 1997). Pregnancy is mentioned in the monograph, but it is not surveyed on the PPE history form shown in the monograph (American Academy of Family Physicians et al., 1997). Magee (1997) mentioned that if a female has had a recent pregnancy the sacroiliac ligaments may have laxity and take three to four months before the ligaments return to their normal state. Questions about a female's onset of menarche and menstrual cycle should be asked.

Descriptive data such as name, address, phone number, sex, age, date of birth, grade, school, sport(s), and personal physician are collected along with emergency contact information. The PPE form in the monograph does not ask for parent/guardian consent for treatment in an emergency. Permission to treat an athlete in an emergency is important when dealing with high school students since they are not legally allowed to make a decision about treatment because they are usually minors.

Currently only 35 of 50 states require a yearly preparticipation physical evaluation (PPE) and also use a form such as the PPE provided in the 1997 monograph. The National Federation of State High School Associations (NFHS) is the governing body of the state high schools. Schnirring (1999) stated that the National Federation of State High School Associations board of directors put out an advisory statement 
regarding the importance and value of a PPE, and stating schools should review their procedures for the PPE every three years. During the review such things as "recent statutory and regulatory changes, whether a specific form should be required, the appropriateness of sport-specific assessment, and who should be authorized to do evaluations" (Schnirring, 1999, p. 25) should be considered.

Lynicki, Nielsen, and Schneider (2000) supported the need for a uniform PPE to help bridge the difference between what sports medicine experts endorse and what is actually practiced by general practitioners. Cantwell (1998) also stated that in the United States the PPE lacks uniformity, with some states having no guidelines and nonphysicians (chiropractors and nurse practitioners) allowed to conduct the PPE. According to Cantwell (1998) not having the knowledge to perform a PPE leaves the athlete at the mercy of the individual conducting the exam and thus the examiners "knowledge, interest, and time available for PPEs will determine the value of the examination" (Cantwell, 1998, p. 59). Cantwell also made some PPE recommendations, such as following guidelines from organizations like the American College of Sports Medicine (ACSM) to develop a uniform form that each state could use. Cantwell recommended that parents be required to review and sign the medical history form.

\section{Summary}

With the variety of PPE forms, and no uniform format, athletes are being evaluated with different criteria. The PPE forms vary in length and criteria covered. Without a proper history and physical evaluation of an athlete there is the possibility of exacerbating an injury during competition, or in the worst case scenario, die from an 
undiagnosed condition. The important aspects of the medical history of the PPE include demographics, cardiac abnormalities, head injury/neurological problems, medications, orthpaedic/previous injuries, gynecological issues, immunizations, and environmental issues. Each of the above mentioned criteria are important because each criterion provides the examiner with information that can aid in the diagnosis of medical conditions or help address areas in which preventative measures can be taken so that athlete do not risk further injury. A thorough physical evaluation is also an important aspect of the PPE. Without the knowledge that can be gained about an athlete during the PPE the consequences may be a severely injured athlete or an athlete who dies from an undiagnosed health issue. This study aimed to look at the criteria that are addressed in the PPE forms used in Santa Clara County high schools and Bay area community colleges. 


\section{Chapter 2}

\section{LITERATURE REVIEW}

Introduction

Over 6 million high school athletes participate in sporting activities annually (Glover, Marion, \& Matheson, 1999). If a student participates in sports for school, he or she is required to have a preparticipation physical evaluation (PPE) prior to playing a school sport. A child's personal physician may conduct the PPE, or in many cases, the evaluation is conducted by a health care professional in the locker room, or training room of the school. Many times the PPE is the only physical exam that a child will have in a given year; however the PPE is not meant to replace the annual physical exam children should receive. The purpose of this section is to present a review of the literature that pertains to the PPE. The focus of this paper is to describe the use of the PPE in high schools and community colleges and the content of the PPE forms currently used by schools. The following topics will be discussed with regard to preparticipation physical evaluations: use, purpose, aspects, parents'/athletes' knowledge, legal aspects, and recommendations from the American Heart Association.

Use of the Preparticipation Physical Evaluation

Feinstein, Soileau, and Daniel (1988) contacted by mail each state and the District of Columbia high school athletic association. High school personnel were asked to provide information regarding the PPE. Feinstein, Soileau, and Daniel received 45 replies and noted that 35 states required yearly exams, six had no requirement (California, Maine, Oklahoma, Oregon, Rhode Island, and Wyoming), and three required 
an exam every three years (Minnesota, Nevada, and Texas). Tanji (1990) stated that there are only 35 states that required a yearly physical exam and doctor's clearance prior to allowing a child to participate in high school sports. Tanji also mentioned similar information for junior high athletes. Although the health and well being of children participating in sports is of concern to parents and physicians, a PPE is not required in all states prior to participation in sport. No uniform PPE form is used by states that do require a PPE each year. Feinstein et al. (1988) noted that each year there are more than 5 million senior high school students that participate in sport programs and several million in junior high school sport programs. Findings of Fields and Delaney (1990) supported Feinstein et al. (1988) that a PPE is needed for 7 million high school students and a similar number of middle school students. Cavanaugh, Miller, and Henneberger (1995) stated that high school athletic competition, in the United States, has roughly 7 million adolescents competing regularly each year. As can be seen by these numbers presented above many student athletes need a PPE each year.

The PPE form may contain a series of questions pertaining to an athlete's history and a physical form for the physician to complete pertaining to the musculoskeletal system and auscultation of heart sounds. The physical contains a section in which the doctor will note if the athlete has been cleared, cleared with restrictions, or not cleared for sport participation (Lynicki et al., 2000). Space should be available for explanation if the athlete is not cleared for participation. Glover and Marion (1998) found annual screenings are required by only 33 states and that 8 of 51 states have no standard history and physical questions for examiners to follow. In an article in Archives of Pediatric and 
Adolescent Medicine by the Board of Trustees (1994), it was reported that only 35 states require a yearly PPE and relatively little consistency is accounted for in the health assessment. Only 35 of 50 states require a yearly evaluation for sport participation, knowing that children will be participating in activities that have high injury risks. Stenger (1993) recommended that an athlete receive an entry-level preparticipation physical and have that followed by limited physicals annually that focus on the problems an athlete may have had over the past year. Thus, athletes should be fully screened upon their first entrance into a program and the subsequent evaluations should be limited to any new problems an athlete presents. Johnson, Kibler, and Smith (1993) suggested that athletes should have a complete screening annually and have minor evaluations as necessary. Also, athletes should be examined with a sport specific evaluation if they plan on playing more than one sport per year.

According to Cantwell (1998) the individual performing the PPE should be a physician, yet other healthcare professionals, such as nurse practitioners and chiropractors, are allowed to evaluate athletes and clear them for sport participation.

Although each state that designates specific examiners recommends that physicians be responsible for preparticipation screening, approximately $\mathbf{5 0 \%}$ sanction alternative clinicians, such as nurse practitioners, physician assistants, or chiropractors, (and in one state, naturopathic clinicians) to provide clearance for sports competition (Glover \& Marion, 1998, p. 1819).

Strong (1994) supported Glover and Marion (1998) in stating that physicians should be the individuals responsible for the performance and supervision of the preparticipation evaluations. Cantwell (1998) found that non-uniformity of the PPE is a 
problem in the United States, and that some states have no guidelines. Cantwell also mentioned that some states allow chiropractors or nurse practitioners to perform PPEs. There is no mandate as to who should perform the PPE for high school athletes, but there are some recommendations. Fields and Delaney (1990) stated that the PPE should take place preferably in an athlete's family physician's office so that the doctor can gain the trust of an athlete and develop some rapport. An evaluation in a doctor's office is also a more favorable atmosphere for physical evaluations because of the privacy that is provided. An evaluation performed by a child's personal physician is preferable, and allows an athlete to receive better guidance and an opportunity to ask for help on personal issues that an athlete might not ask about if the evaluation were given in mass form at the school. An athlete's personal physician also may have prior knowledge of the client and his or her family history. McKeag (1985) listed some advantages of having the evaluation performed by the primary care physician.

The advantages were:

(a) past medical history is already known by the examiner

(b) motivation can be better assessed with this knowledge

(c) when the relationship between doctor and patient is already established discussion of sensitive issues can be facilitated

(d) greater continuity of care, results, especially if eventual injury becomes a concern

(e) if medical consultation is desired arrangements can be quick and the follow-up more complete. (p. 416)

Other options that exist for performing the PPE are mass evaluation in locker/changing room areas, or station evaluation (Henderson, 1992; McKeag, 1985). Station evaluation is where a few healthcare professionals work at the screening and each is in charge of a 
particular task such as heart/lungs, musculoskeletal exam, vision testing, blood pressure, height, and weight.

In addition, a Report of the Board of Trustees in the Archives of Pediatric and Adolescent Medicine (1994) recommended that only licensed physicians or doctors of orthopaedics (DO) should perform the PPE. The medical societies from each state should work closely with state and local agencies to develop and endorse consistent standards among schools for the PPEs. The PPE is used to help ensure the health and safety of children and young adults who participate in sports and therefore licensed physicians should clear children for sport participation.

Purpose of the Preparticipation Physical Evaluation

The PPE, like an annual physical, is meant to check the health condition of an athlete prior to sport activity. The PPE is not meant to replace the annual physical, nor is it a comprehensive evaluation of an athlete's medical status (Krowchuk, Krowchuk, Hunter, Zimet, Rainy, Martin, \& Curl, 1995). Disqualifying athletes from participation in sport is not a goal of the PPE (Report of the Board of Trustees, 1994). The PPE is an evaluation that will take less than five minutes if done in mass exam style and may be slightly longer if athletes visit their personal physicians in their offices. An athlete should completely fill out the medical history portion honestly and have it checked and signed by a parent or guardian to help ensure that the medical history questions were answered correctly. If an athlete is not sure of a question he or she may ask his or her parents or guardians for help and clarification. Dyment (1992) mentioned that the top priority of the PPE is the detection of those athletes who would be at risk during 
competition. McKeag and Sallis (2000) followed the idea mentioned by Dyment (1992) in a statement of the purpose of the PPE:

It is to establish primary care in adolescents who frequently do not have a physician, to provide an opportunity for adolescents to talk to a physician about sports-related or development issues and to identify any health risks inherent in a particular sport. (p. 2617)

Hergenroeder (1997) suggested that since the PPE does not cover topics such as drug use, sexual activity, violence, mental health, and immunizations, the evaluation is not a comprehensive evaluation like an athlete might receive if he or she had a yearly physical from a primary care physician. A majority of high school athletes use the evaluation as a substitute for their annual comprehensive physical evaluation by their family physician (Hergenroeder, 1997).

The health of an athlete is a main objective of the PPE. Rifat, Ruffin, and Gorenflo (1995) stated the health and safety of an athlete during competition are the goals of the evaluation. If an athlete has a physical problem, or medical condition, and is not able to play to the best of his or her ability, the PPE is used to try to identify those problems so that an athlete can play safely and without limitations. Samples (1986) mentioned that management of health problems, identification of previous injuries, injury prevention, and fitness assessment are also important goals of the PPE. To some athletes the PPE may seem like a formality and/or a waste of time since all they really want to do is go out and play their particular sport. Krowchuk et al. (1995) mentioned that the PPE is used to find medical and orthopaedic conditions that might influence the safety of an athlete during competition. Tennant, Sorenson, and Day (1981) stated that the PPE seems to find individuals who would not be able to safely participate in athletics without 
the correction of a medical condition. They also mentioned that the PPE may lead to early detection and treatment of preexisting medical problems of the athlete.

Tanji (1990) layed out the goals of the PPE, when he stated that:

The preparticipation physical examination has several specific goals: (1) to identify any condition that could disqualify a child from participation in a specific sport; (2) if a disqualifying condition is discovered, to determine whether is can be corrected or whether preventive measures can be taken to allow participation; ( 3 ) if the child is disqualified from the initially desired sport, to suggest another, more appropriate sport, and (4) to assess the general medical status of the child and recommend treatment for any potentially serious condition. An underlying goal of the preparticipation physical examination is to encourage young people to engage in organized sports and fitness activities, which promote health and help prevent disease. (p. 397)

Hergenroeder (1997) and Tanji (1990) agreed on some of the same objectives for the PPE. Hergenroeder (1997) supported that objectives of the PPE should include finding treatable conditions and undetected diseases, prevent further injury through identification and treatment of musculoskeletal abnormalities, and the fulfillment of legal and insurance requirements. The idea behind the PPE is not to disqualify athletes from participating in sport, but to perform a medical screening on an athlete so that he or she can participate in sport safely and in a healthy manner. The PPE is also used to identify previous injuries an athlete may have sustained and give the physician an opportunity to suggest some rehabilitation activities an athlete may perform to reduce his or her risk of injury to the same area again.

Aspects of the Preparticipation Physical Evaluation

In 1995 Cavanaugh, Miller, and Henneberger stated there were over 7 million high school adolescents competing in athletics in the United States. Tanji (1990) mentioned that the PPE should not replace an athlete's complete annual history and 
physical. Even though the PPE should not replace a child's annual physical exam, Dyment (1992) stated that $80 \%$ of athletes would use the PPE as their only physical evaluation for the year. The evaluation should not be too simple that an athlete sustains an injury that could have been avoided. The PPE is used to help protect the health of an athlete as he or she plays in vigorous sporting activities.

According to Glover, Marion, and Matheson (1999) the first PPE began 30 years ago and was very simplistic. Only three topics were addressed related to an athlete's heart, whether or not he or she had a hernia, and how an athlete was doing or feeling. According to Glover et al. (1999) the first generation PPE emphasized detecting heart murmurs and asymptomatic hernias. Glover et al. (1999) stated that when the secondgeneration examination came out it had added a question that asked whether or not the individual had any past medical history problems. Having a question pertaining to past medical problems could lead the physician to evaluate other areas if a child answers yes to one of the medical history questions. As Tucker (1999) stated, during the history or musculoskeletal evaluation, a lot of the problems that would withhold an athlete from participation become evident, e.g., cardiac problems or unresolved previous injuries.

The PPE should be performed yearly and prior to the sporting activity, yet how soon before the activity should a child be given the evaluation. Tanji (1990) stated that the PPE should be conducted one month prior to formal competition to allow for followup evaluation and treatment as needed. With the PPE given at least one month prior to competition an athlete is not held out of practice or competition for an injury condition. Stenger (1993) and Gemberling (1996) mentioned that the PPE should take place six 
weeks before an athlete's season to allow for time to further evaluate and treat found abnormalities that might keep an athlete from competing. Mellion (1994) concurred that the PPE should be conducted four to six weeks before a season begins, but not so far in advance that development of new problems could be a factor.

A PPE evaluates injuries or past medical conditions that might affect an athlete's health during sport participation. Johnson et al. (1993) stated the PPE should at least assess risk factors and evaluate injury conditions that might lead to the unsafe sports participation of the athlete. The athlete may fill out a questionnaire pertaining to his or her medical history so that the examining physician is given some information regarding past health. Feinstein et al. (1988) found that $31 \%$ (11 of 36) of the PPE forms that were returned to them had no medical history questions and in the other $69 \%$ ( 25 of 36 ) of the PPE forms the medical history questions ranged in number from 1 to over 200 questions. One medical history question would not give the physician enough information to determine the health of an athlete and 200 questions could be looked at as too much information and too time consuming to fill out. There is no appropriate number of questions for a medical history form. The medical history form should have enough questions to help the physician, along with the physical evaluation, determine the health of an athlete. The PPE form that the American Academy of Family Physicians et al. (1997) endorsed has 43 questions. Feinstein et al. (1988) stated parents are asked to give consent for emergency treatment of their children in only 21 states. In Feinstein et al. (1988), of all the PPE forms that were returned, only 21 of 36 (58\%) had a section where the parents would sign for consent of emergency care for their children. For those states 
that do not have such a policy, parents should make it known that they would like such a policy placed into the PPE form or as a separate form. Knowing that a majority of athletes use the PPE as their only medical evaluation of the year Feinstein et al. (1988) mentioned that parents should be told the purpose and limits of the PPE. The parents should also try to establish their children's care with primary care providers or family doctors.

One major aspect of the PPE that plays a role in uncovering past medical problems is the medical history form. With both the parents and athletes going over this form and answering each question truthfully, a physician can obtain important information about a child and can gear the evaluation towards areas in which a child gave a positive answer. Koester (1995) stated

The literature clearly points to the conclusion that with a thorough history and a focused physical examination, the PPE may uncover medically disqualifying conditions ... (and) an accurate history is the most vital aspect of the PPE to ascertain an athlete's risk of physical injury. (p. 353) In an article titled "Preseason Physical Examinations" (1990), in the American Journal of Sports Medicine, it was established that the PPE should contain a medical history, an orthopedic evaluation, measurements of blood pressure, height, weight and skin fold along with questions regarding exercise-induced bronchospasm. Rifat et al. (1995) alluded to the idea that key medical questions and physical evaluation items are important details of the PPE and should be part of the questionnaire and evaluation. Matheson (1998) stated in a survey conducted by Bradford and Lyons (1991), they found that of the 114 public schools districts surveyed in Pennsylvania, 25\% had no medical history portion, and $60 \%$ with no musculoskeletal examination as part of the PPE. 
Matheson (1998) mentioned the medical history is the most sensitive method for finding problems.

In the medical history section of the PPE there should be a section pertaining to cardiovascular history. Drezner (2000) stated that the cardiovascular history questions should pertain to previous exercise induced chest pain/discomfort, exercise induced syncope, light-headedness, fatigue that is not proportionate to the exercise, and any history of palpitations or skipped heart beats. Use of drugs, having an elevated blood pressure or a heart murmur should also be items that are noted. Drezner noted that in a survey of the 50 states and the District of Columbia, eight states history and physical questions were non-approved and 12 states had inadequate questionnaires according to the American Heart Association. One state did not even have a formal requirement for screening. Mellion (1994) mentioned the items stated by Drezner (2000) along with chest pain associated with exercise, history of hypertension, and a family history of sudden cardiac death prior to age 50 years.

The PPE form should contain questions that can be answered with yes/no responses and have a section in which the yes responses can be explained in some detail. The PPE form may start with a yes/no question and if the answer is positive there will be a space for explanation for the positive response at the end of the PPE form. Fields et al. (1990) listed a set of questions that could be used as the medical history aspect of the PPE. The areas that are covered by the questions are cardiovascular risk, exerciseinduced asthma, musculoskeletal injury, neurological injury, heat-related illness, harmful 
health habits, and general health screening. The questions from Fields et al. are as follows:

1. Has anyone in the athlete's family (grandmother, mother, father, brother, sister, aunt, uncle) died suddenly before the age of 50 years?

2. Has the athlete ever passed out during exercise or stopped exercising because of dizziness?

3. Does the athlete have asthma (wheezing), hay fever, or coughing spells after exercise?

4. Has the athlete ever broken a bone, had to wear a cast, or had an injury to any joint?

5. Does the athlete have a history of concussion (getting knocked out)?

6. Has the athlete ever suffered a heat-related illness (heat stroke)?

7. Does the athlete have anything he or she wants to discuss with the physician?

8. Does the athlete have any chronic illness or see a physician regularly for any particular problem?

9. Does the athlete take any medicine?

10. Is the athlete allergic to any medications or to bee stings?

11. Does the athlete have only one or any paired organ (eyes, ears, kidneys, testicles, ovaries, etc.)? (p. $305-307$ )

One example of a medical history and PPE form is the one backed by five organizations (American Academy of Family Physicians, American Academy of Pediatrics, American Medical Society for Sports Medicine, American Orthopaedic Society for Sports Medicine, and American Osteopathic Academy of Sports Medicine). The form was developed for a monograph entitled Preparticipation Physical Evaluation. It was originally written in 1992 and was revised in 1997.

In an article put of by the American Heart Association by Maron, Thompson, Puffer, McGrew, Strong, Douglas, Clark, Mitten, Crawford, Atkins, Driscoll, and Epstein (1996) they recommended that blood pressure and heart sound auscultation should be part of the physical evaluation. According to Glover et al. (1998) the American Heart Association preparticipation cardiovascular screening recommendations include: 
(1) family history of premature sudden death or heart disease in surviving relatives, (2) personal history of heart murmur, systemic hypertension, excessive fatigability, syncope, exertional dyspnea or chest pain, as well as parental verification of the history, (3) physical examination for heart murmur, femoral pulses, stigmata of Marfan syndrome or blood pressure measurement, which includes the recommendation of precordial auscultation in both the supine or sitting and standing position to identify heart murmurs consistent with left ventricular outflow tract obstruction. (p. 1817)

Shrier (2001) mentioned that a study conducted by Pfister, Puffer, and Maron (2000) found that only 163 of 625 National Collegiate Athletic Association (NCAA) colleges and universities had history and PPE forms that contained at least 9 of the 12 recommended American Heart Association screening guidelines. Of those $625 \mathrm{PPE}$ forms that were reviewed 150 had 4 or less guidelines. Shrier mentioned that the study was gathering information about the administration and scope of the PPE procedures. The information was gathered from team physicians or athletic directors and the study was also looking at how the PPE forms compared to the 12 recommended items by the American Heart Association. In reviewing the 1996 American Heart Association preparticipation screening recommendations Glover et al. (1998) mentioned that $40 \%$ of state high school associations do not have an approved medical history and physical evaluation forms, no requirements for screening, or have forms that are deficient compared to the American Heart Association guidelines and recommendations. Koester (1995) mentioned that to discover an athlete's physical injury risk an accurate history is the most important aspect. Rifat et al. (1995) agreed with Koester (1995) that medical history and a few key evaluation items were vital aspects of the PPE. Carek, 
Futrell, and Hueston (1999) mentioned a complete medical history could identify roughly $75 \%$ of problems that affect athletes.

Parents'/Athletes' Knowledge of the Prepaticipation Physical Evaluation

Parents and athletes alike may wonder why a PPE is needed if an athlete is feeling fine. The PPE may be used as the only medical exam received every year, instead of a complete yearly physical examination by an athlete's regular physician. Krowchuk et al. (1995) conducted a study about parents' knowledge of the PPE, the parents' plan to use the PPE as the only medical evaluation for their children, their reason for such a decision, and their knowledge of the objectives of the PPE. They found that both parents and student athletes see the PPE as a good medical assessment of an athlete's health, and that many parents do not have any other medical care that they can refer to, so they do not seek further evaluation. Parents know that the PPE is important in finding problems that may hinder the playing ability of their children during athletic participation. They also reported that other aspects should be included in the PPE such as health issues unrelated to sports, health screenings, behavioral and social issue assessments, and immunizations. Parents were also asked about how often their children received a comprehensive physical evaluation and how often they thought a comprehensive evaluation should be performed. Krowchuk et al. (1995) found that parents had different beliefs on when a comprehensive physical evaluation should be conducted. A majority of the parents believed that children should receive an annual evaluation, a quarter of parents thought an evaluation every two years was appropriate, and a few parents thought an evaluation semiannually or triennially was appropriate. Many different opinions on how often a 
physical should be performed exist in the literature. Krowchuk et al. (1995) mentioned the American Medical Association (AMA) Guidelines for Adolescent Preventive Services (GAPS) suggesting that individuals between the ages 11 to 21 years should have an annual health assessment.

A child's attitude towards the PPE varies from his or her parents' attitude according to Krowchuk et al. (1995). Hergenroeder (1997) found $30 \%$ to $78 \%$ of adolescents would use the PPE as a substitute for an annual comprehensive physical evaluation. Krowchuk et al. (1995) mentioned that three-quarters of the parents of student athletes that were surveyed planned to have their children receive a comprehensive evaluation in the year following the PPE. Carek and Futrell (1999) stated that many athletes felt they could participate safely in sports without having had a PPE, even though most athletes felt the PPE could help or prevent injuries. If athletes, along with their parents, believe that the PPE could help prevent some injuries, why are more athletes not participating or having PPEs performed prior to their sporting activity?

\section{Legal Aspects of the Preparticipation Physical Evaluation}

According to Maron et al. (1996) educational institutions and professional sport organizations must provide reasonable care in running their athletic programs. There is no law requiring the institution or organization to provide a PPE to find notable medical abnormalities. With no set requirements incorporated by law or athletic governing bodies in place governing the PPE each school or team rely on a team physician to conduct the PPE and determine pertinent screening procedures. Maron et al. (1996) stated that the 
medical profession is allowed to form the scope of the screening of athletes based on its collective medical judgment.

According to American Academy of Family Physicians, American Academy of Pediatrics, American Medical Society for Sports Medicine, American Orthopaedic Society for Sports Medicine, American Osteopathic Academy of Sports Medicine (1997) there are three issues of importance regarding the PPE. The first issue is that of assumption of risk and liability when an athlete wishes to participate despite restrictions placed during the evaluation. The athlete may have a legal right to participate against medical advice. The restricting physician should consult with an expert in the medical condition to determine the amount of risk to an athlete if he or she chooses to participate in sports. Both physicians should fully explain the risks to an athlete who has been restricted from participation in sport. Also, the physicians should document the discussions that are held with an athlete and/or his or her parents.

The second issue the American Academy of Family Physicians et al. (1997) deals with is sexual improprieties. Allegations may come from evaluations that are performed in station-based style because of the unfamiliarity of the physician to an athlete. Physicians should exercise common sense and inform athletes of the extent of the evaluation. The evaluation should take place in a proper setting and physicians should use discretion with comments and actions that may be misunderstood by athletes.

The Good Samaritan Statutes are the third issue of concern with regard to the PPE according to the American Academy of Family Physicians et al. (1997). Each state has its own statutes and it is important for the physician who conducts the evaluations to 
know the state's statutes. This means that if the evaluating physician wishes to be protected under the Good Samaritan Statutes, he or she cannot accept any type of compensation for performing the PPE.

Another area of concern for physicians who perform the PPE is that of liability. Gallup (1995) addressed this issue in regards to failure to diagnose a medical condition. There are three major areas of concern for the physician. Gallup (1995) stated these areas as cardiac anomalies, arrthythmias, and sudden cardiac death. If a physician misdiagnoses one of the above mentioned problems, the athlete is placed at a greater risk and the result of the physicians misdiagnosis may be fatal. Another domain mentioned by Gallup (1995) in which the physician may be liable is that of failing to diagnose a previous injury or condition. With a physician's failure to properly diagnose an athlete there is further risk of injury by participating in a sporting activity.

Recommendations from the American Heart Association Maron et al. (1996) discussed the American Heart Association (AHA) recommendations regarding the PPE. One recommendation was that a history and physical evaluation be conducted prior to organized sport participation in high school (grades 9 through 12) and college.

Also, a national uniform form for the PPE should be developed. Healthcare professionals with the proper training and medical background to obtain a detailed cardiac history, perform the physical evaluation, and identify heart disease should conduct the PPE. More specifically, a complete medical history and physical evaluation, 
with a brachial blood pressure measurement, should be performed during athletic screening evaluations.

\section{Summary}

The use, purpose, and aspects of the PPE have been examined along with the reasons that each child should receive a yearly physical evaluation. Both parents and children seem to believe that the PPE would be helpful in reducing risk of injury during practice or competition.

According to Glover et al. (1999) the PPE has been around for 30 years. It is an examination that has been and could use continual updating and input from the medical practitioners involved with a PPE. For example the American Academy of Family Physicians et al. (1997) revised their 1992 Preparticipation Physical Evaluation in 1997. Those individuals that are involved with PPEs do agree that it is a useful form and helpful in trying to reduce the number of athletes that become injured during sporting activity.

Tanji (1990) found that 35 of 50 states require an annual physical evaluation prior to participation in athletics. It is important for each state to have a requirement for an annual PPE for those involved in sport activity. Not only does the evaluation better ensure the health and safety of athletes, it also is used to identify injuries or problems that might have gone unchecked if an athlete was only required to have a PPE every two or three years. Along with the National Federation of State High School Associations, there should be another advisory committee that examines the creation of a national uniform form that includes all the necessary medical history questions, including following the American Heart Association's 13 guidelines for cardiovascular screening, and a proper 
physical evaluation. This committee should include physicians, athletic trainers, and state high school association members.

Over time the PPE has changed and will probably continue to change. It is up to those involved to maintain high standards for the PPE and not minimize its value. 


\section{Chapter 3}

\section{METHOD}

The purpose of this study was to descriptively analyze the content of preparticipation physical evaluation (PPE) forms used in Santa Clara County high schools and Bay area community colleges. This study was conducted by distributing a letter via United States mail to athletic directors in Santa Clara County high schools and San Francisco Bay area community colleges requesting a copy of the PPE form used and asking them to fill out a short survey form. Upon completion of the descriptive analysis a synthesis of the results was given to all surveyed high schools and community colleges.

\section{Participants}

The unit for analysis in this study was the PPE form returned by high schools in Santa Clara County and community colleges in the San Francisco Bay Area. These areas were selected because of the close proximity to the principal investigator's place of employment and the desire to determine the use of the PPE forms in local schools. The researcher collected PPE forms from 26 of 57 (46\%) high schools and 8 of $17(47 \%)$ community colleges.

There are 11 community college districts in the Bay area in which there are 22 community colleges. The 17 community colleges surveyed for this study cover from San Francisco to Monterey and from San Mateo to Livermore, and are listed under the Coast Conference in the Commission on Athletics 2001-2002 Directory.

Fifty-seven high schools and 17 community colleges were surveyed for this study. The response rate was 42 for high schools ( $74 \%$ ) and 11 for the community colleges 
$(65 \%)$. The response rates listed above include the schools that returned either their PPE form, the survey, or both.

Santa Clara County covers 1,312 square miles, has a population of $1,736,700$ people, and has 5 high school districts. In those 5 districts there are 63 high schools. Athletic programs are present in $\mathbf{5 7}$ high schools. Santa Clara County spends an average of $\$ 7,202$ on each high school student per fiscal year. Two high schools in Santa Clara County, Pioneer and Santa Clara, were given the 2001 California Distinguished School Award (http://www.sccoe.org). In one district there are 8,973 students enrolled in the high schools. In that district the employee's salaries and benefits added up to $82 \%$ of the districts actual expenditures $(\$ 48,578,898$ of $\$ 59,337,425)$. Ninety percent of the students from that district continue on to college with $53 \%$ of them entering a 4-year university (http://www.fuhsd.org).

In another district the student enrollment is 2900 and the teachers salaries range from $\$ 47,738$ to $\$ 90,202$. Both schools in this particular district have been recognized as California Distinguished schools in the past (http://mvla.k12.ca.us).

Another district covers 180 square miles and has a student enrollment of 24,500 students. The district employs 1357 certified teachers, 813 classified members and 314 adult education teachers. The community is home to a population of 434,000 people. There are 10 high schools in the district. Four of the high schools have been recognized as California Distinguished Schools, and six of the schools are Digital High Schools (http://www.esuhsd.org). 
Another high school district has an enrollment of 7394 students and spent $\$ 6,093.92$ per student. The teacher's salaries range from $\$ 35,535$ to $\$ 68,354$. The ethnic groups that make up the student enrollment are American Indian, Asian, Pacific Islander, Filipino, Hispanic, Black, and White and the class sizes are an average of 28 students per class (http://www.cuhsd.org).

The last school district has two high schools. One of the schools has an enrollment of approximately 1250 students where over $99 \%$ of the graduating seniors enroll in college with $75 \%$ enrolling in four-year universities. The school has received the California Distinguished High School Award as well as National Recognition of Excellence. The other high school has been given the California Distinguished School award twice and two National Secondary Blue Ribbon Recognition awards. The school has 1500 students. The respective average class size for the two schools are 28 and 29 students respectively. The average teachers' salaries for the district range from $\$ 31,624$ to $\$ 69,535$. The total expenditure for the district was $\$ 20,199,470$ which represents $\$ 7,450.93$ per student (http://www.lgsuhsd.org).

\section{Instrument}

The instrument for this study included: an envelope mailed to athletic directors with a letter (Appendix A) inviting high schools and community colleges to participate in the study; a short PPE survey (Appendix B) to determine what a school uses when no PPE is available, and the frequency of required medical examinations was determined. A PPE data sheet (Appendix C) was designed to record the presence of demographic questions, cardiac abnormalities, head injury and neurological problems, medications, 
orthopaedic and previous injuries, gynecological questions, immunizations, and environmental questions on the returned PPE forms.

\section{Procedures}

Prior to the beginning of the data collection approval was sought from the San Jose State University Institutional Review Board. A copy of approval letter from the Institutional Review Board (IRB) can be found in Appendix G. Names and addresses of high school athletic directors were gathered from the FERMAR Corporation 2001-2002 Sports Directory. The directory includes schools in the Santa Clara Valley League, Blossom Valley Athletic League, West Catholic Athletic League, Valley Youth League and Northern California College Soccer. Names of the college athletic directors were obtained from the Commission on Athletics 2001-2002 Directory. The community colleges surveyed are in the Coast Conference section.

A letter was mailed to athletic directors of high schools in Santa Clara County and community colleges in the San Francisco Bay area (see Appendix A) requesting a copy of the PPE form used and a short PPE survey (see Appendix B). A self-addressed stamped envelope was provided for return. If the school did not use a PPE form, the Athletic Director was asked to indicate if and what the parents completed prior to students' participation in athletics to prove that athletes were cleared to participate in sports. A follow-up phone call was made to each of the athletic directors one week after the initial mailing to confirm that the athletic directors had received the mailed envelope.

The self-addressed stamped envelopes were coded on the front lower left corner. The code corresponded to a school so that the investigator could keep track of responding 
schools and to maintain anonymity. The coding system was systematic and known only to the principal investigator.

Following a 3-week waiting period, if the information was not returned, a followup letter was mailed (see Appendix D). Once the forms were gathered from the high schools and community colleges, each form was examined for its content and using Appendix $C$ and the check off sheet the results of the survey were examined.

Athletic directors of the high schools and community colleges were asked to return a copy of the PPE used at their institution, along with a short survey. The letters were mailed in early March 2002 and a follow-up phone call was made to each athletic director one week after the letters were mailed to confirm that the athletic director received the initial mailing.

\section{Design and Analysis}

The PPE Data Sheet (Appendix C) was used to record all variables used in a school's PPE form. The measured variables were demographic information, cardiac abnormality, head injury/neurological problems, medications, orthopaedic problems, gynecological, immunizations, and environmental. The variables were compared to the returned PPE form and if the PPE form matched the variable on the data sheet a 1 was placed in the box corresponding to the variable. If the schools PPE form did not contain the variable on the data sheet a 0 was placed in the box corresponding to the variable. A blank box indicated that the school did not return a PPE form and therefore no data could be gathered for or against the measured variables. Data were descriptively analyzed by reporting the frequency of high school and community college participants that measure 
that variable. A synthesis of the results was then sent to Santa Clara County high schools and San Francisco Bay area community colleges (see Appendix F). The results were divided into areas that needed minor changes and areas that needed major changes. To be included in the minor change area at least $50 \%$ of the variables measured for a particular category (i.e., demographics) had to appear in at least $50 \%$ of the examined PPE forms. To be placed in the major change area meant that less than $50 \%$ of the variables measured for a particular category (i.e., demographics) appeared in less than 50\% of the PPE forms examined. 


\section{Chapter 4}

\section{RESULTS}

Fifty-seven high schools and 17 community colleges were identified as fitting the sample characteristics of Santa Clara County high schools and San Francisco Bay area community colleges. The response rate was 42 of 57 for the high schools (74\%) and 11 of 17 for the community colleges $(65 \%)$. The athletic directors of the high schools and community colleges were asked to return a copy of the preparticipation physical evaluation (PPE) form used at their respective institution, along with a short survey. Letters were mailed in March 2002 and a follow-up phone call was made to each athletic director one week after the letters were mailed to confirm that they had received the initial mailing. The purpose of the study was to evaluate the PPE forms used in high schools and community colleges. In the $42(74 \%)$ responses from the high schools 26 (62\%) returned the PPE form used at their school and $39(93 \%)$ also returned the survey. From the $11(65 \%)$ responses from the community colleges $8(73 \%)$ returned the PPE form and $10(91 \%)$ aiso returned the survey. In the responses from the high schools, 17 of $42(40 \%)$ only returned the survey. The community colleges had 3 of $11(27 \%)$ return the survey only.

PPE forms were reviewed for eight variables including demographics, cardiac abnormality, head injury/neurological problem, medications, orthopaedic/previous injury, gynecological, immunization, and environmental (heat illness and asthma). Data from the returned PPE forms were coded on the PPE Data Sheet (see Appendix C). A one was placed in the box corresponding to an item listed on the PPE form and a zero when the 
item was not listed (see Appendix E). A blank box indicated PPE forms that were not returned so no PPE variables could be identified for that institution.

Percentages were calculated to determine the use of each item on the returned PPE forms. Table 1 provides the percentages for each item under its respective category for the high school and community college PPE forms. A total of 44 items were measured.

Table 1.

Demographic Information

Variable High Schools $(n=26)$

Community College $(n=8)$

\begin{tabular}{|c|c|c|c|c|}
\hline & (n) & $(\%)$ & $(n)$ & (\%) \\
\hline Name & 26 & 100 & 8 & 100 \\
\hline Age & 12 & 46 & 3 & 37.5 \\
\hline Sex & 13 & 50 & 6 & 75 \\
\hline Grade level & 19 & 73 & 2 & 25 \\
\hline Address & 21 & 81 & 4 & 50 \\
\hline Phone number & 21 & 81 & 4 & 50 \\
\hline Sport & 15 & 58 & 6 & 75 \\
\hline Parent/guardian signature & 25 & 96 & 2 & 25 \\
\hline Physician signature & 26 & 100 & 8 & 100 \\
\hline Proof of exam & 12 & 46 & 8 & 100 \\
\hline Drug/Supplement use & 2 & 8 & 4 & 50 \\
\hline Height & 12 & 46 & 8 & 100 \\
\hline Weight & 12 & 46 & 8 & 100 \\
\hline Blood Pressure & 12 & 46 & 8 & 100 \\
\hline Emergency Contact & 13 & 50 & 3 & 37.5 \\
\hline $\begin{array}{l}\text { Permission to treat } \\
\text { in emergency }\end{array}$ & 12 & 46 & 2 & 25 \\
\hline \multicolumn{5}{|l|}{ Cardiac Abnormality } \\
\hline $\begin{array}{l}\text { Cardiac history } \\
\text { Sudden death of }\end{array}$ & 8 & 31 & 5 & 62.5 \\
\hline $\begin{array}{l}\text { family member } \\
\text { Chest pain during }\end{array}$ & 13 & 50 & 4 & 50 \\
\hline exercise & 12 & 46 & 3 & 37.5 \\
\hline
\end{tabular}


Table 1 continued

\begin{tabular}{|c|c|c|c|c|}
\hline $\begin{array}{l}\text { Heart murmur } \\
\text { Heart condition denying } \\
\text { participation }\end{array}$ & 6 & $\begin{array}{l}23 \\
19\end{array}$ & 0 & $\begin{array}{l}62.5 \\
0\end{array}$ \\
\hline \multicolumn{5}{|c|}{ Head Injury Neurological Problems } \\
\hline Head injury/concussion & 12 & 46 & 7 & 87.5 \\
\hline $\begin{array}{l}\text { Seizures } \\
\text { Stingers/burners/ }\end{array}$ & 13 & 50 & 4 & 50 \\
\hline $\begin{array}{l}\text { pinched nerves } \\
\text { Headaches }\end{array}$ & $\begin{array}{c}6 \\
10\end{array}$ & $\begin{array}{l}23 \\
38\end{array}$ & $\begin{array}{l}3 \\
3\end{array}$ & $\begin{array}{l}37.5 \\
37.5\end{array}$ \\
\hline $\begin{array}{l}\text { Numbness/tingling } \\
\text { in extremities }\end{array}$ & 5 & 19 & 1 & 12.5 \\
\hline \multicolumn{5}{|l|}{ Medications } \\
\hline $\begin{array}{l}\text { Current medication } \\
\text { Allergies } \\
\text { Vitamins/supplements }\end{array}$ & $\begin{array}{l}10 \\
13 \\
4\end{array}$ & $\begin{array}{l}38 \\
50 \\
15\end{array}$ & $\begin{array}{l}7 \\
7 \\
2\end{array}$ & $\begin{array}{l}87.5 \\
87.5 \\
25\end{array}$ \\
\hline
\end{tabular}

Orlhopaedic. Previous Injuries

Special equipment or

$\begin{array}{lllllll}\text { corrective devices } & 5 & 19 & 1 & 12.5\end{array}$

Vision

1246

$8 \quad 100$

Sprain, strain, fracture,

1246

$\begin{array}{ll}7 & 87.5\end{array}$

Loss of paired organ

$8 \quad 31$

Previous injury

1246

Previous surgeries

1350

$2 \quad 25$

Hospital stays

1350

$7 \quad 87.5$

675

Skin problems

$6 \quad 23$

$3 \quad 37.5$

$2 \quad 25$

Gynecological

Onset of menarche

$4 \quad 15$

$1 \quad 12.5$

Most recent menstrual cycle

Time between cycles

Pregnancy

$\begin{array}{cc}4 & 15 \\ 4 & 15 \\ 0 & 0\end{array}$

$3 \quad 37.5$

$5 \quad 62.5$

0 0 
Table 1 continued

Immunizations

Immunizations (Tetanus, Measles, Hep B, Chicken Pox)

$10 \quad 38$

$3 \quad 37.5$

Environmental

Heat illness

$12 \quad 46$

Asthma

$5 \quad 19$

$6 \quad 75$

$6 \quad 75$

In the high schools, 35 reported that they required a physical once a year, 14 checked that they required a physician's note, five required a note from the parents, one identified that a physical was required prior to participation in each sport, and five checked the 'other' box. One respondent commented that if the physician is willing to accept the responsibility, an athlete may go two years between physical exams. Two surveys were returned with no information about how often they require a physical for athletes. Some of the high schools checked both the physician's note box and the once a year physical evaluation box, thus that particular school was counted twice.

From the surveys that were returned from the community colleges 9 of $10(90 \%)$ checked that a physical is required once a year, two required a physician's note, one college marked that a physical is required prior to each sport, and one college checked the "other" box. Some of the community colleges identified both the physician's note box and the once a year physical evaluation box, thus that particular school was double counted in the survey. 
Demographic items (see Table 1) identified that in the high schools 9 of $16(56 \%)$ PPE items were at/or above 50 percent compared to 11 of $16(69 \%)$ for the community colleges. Items that were most often asked (more than $50 \%$ of the time) by the high schools were about name, sex, grade level, address, phone number, sport, parent/guardian signature, physician signature, and emergency contacts. The community colleges most often asked items (more than $50 \%$ of the time) were name, sex, address, phone number, sport, physician's signature, proof of exam, drug or supplement use, height, weight, and blood pressure. The items that were most often omitted by either the high school or community college were age of the athlete ( $46 \%$ and $37.5 \%$ respectively) and permission to treat in the event of an emergency ( $46 \%$ and $25 \%$ respectively).

High school PPE forms had lof $5(20 \%)$ items at/or above $50 \%$ compared to 3 of $5(60 \%)$ items for the community colleges about items pertaining to cardiac abnormality (see Table 1). Two item percentages that stand out are the cardiac history ( $31 \%$ for high schools and $62.5 \%$ for community colleges) and heart condition denying participation ( $19 \%$ for high schools and $0 \%$ for community colleges). The number of community college PPE forms that inquire about cardiac history items is double that of high school PPE forms (62.5\% and $31 \%$ respectively). Not many of the community college nor the high school PPE forms inquire about an athlete being held out of participation due to a heart condition ( $0 \%$ and $19 \%$ respectively). Another item that was omitted in a majority (54\% of high schools and $62.5 \%$ of community colleges) of the PPE forms was regarding chest pain during exercise. 
The high school PPE forms had 1 of $5(20 \%)$ items at/or above $50 \%$ while the community college PPE forms only had 2 of $5(40 \%)$ items at/or above $50 \%$ for items pertaining to head injuries and neurological problems (see Table 1). Items that appeared most often on the PPE were regarding head injury/concussion ( $46 \%$ for high schools and $87.5 \%$ for community colleges) and seizures ( $50 \%$ for both). For both the high school and community college PPE forms, rarely did items about stingers/burners/pinched nerves ( $23 \%$ and $37.5 \%$ respectively), headaches ( $38 \%$ and $37.5 \%$ respectively), or numbness/tingling in extremities (19\% and $12.5 \%$ respectively) appear in the PPE.

High school PPE forms had 1 of $3(33 \%)$ items at/or above $50 \%$ while the community colleges had 2 of $3(67 \%)$ items at/or above $50 \%$ for items pertaining to medications, vitamins/supplements that the athlete may be taking, or any athlete allergies (see Table 1). The community college PPE forms had items regarding medications (87.5\%) and allergies (87.5\%), yet didn't have items about vitamin/supplement use (25\%). The high school PPE forms had items most often about allergies (50\%) and did not often ask items about current medications (38\%) or vitamin/supplement use (15\%).

High school PPE forms had 2 of $8(25 \%)$ items at/or above $50 \%$ compared to the community college PPE forms that had 4 of $8(50 \%)$ items at/or above $50 \%$ for items about orthopaedic problems and previous injuries (see Table 1). The only items to appear at least half the time on the high school PPE form were regarding previous surgeries and hospital stays ( $50 \%$ for both). A minority of the PPE forms had items pertaining to special equipment/corrective devices (19\%), vision (46\%), sprains/strains/fractures/dislocations (46\%), loss of a paired organ (31\%), previous 
injuries (46\%), and skin problems (23\%). The community college PPE forms had a slightly higher percentage on items pertaining to vision (100\%), sprains/strains/fractures/dislocations (87.5\%), previous injuries (87.5\%), and previous surgeries (75\%) than the high school PPE forms. The community colleges did not often ask items in the areas of special equipment/corrective devices (12.5\%), loss of a paired organ $(25 \%)$, hospital stays $(37.5 \%)$, and skin problems $(25 \%)$.

High schools had 0 of $4(0 \%)$ items at/or above 50 percent while the community colleges had on 1 of 4 (25\%) items at/or above 50 percent for items pertaining to gynecological questions (see Table 1). Neither the high school nor community college PPE forms inquired about pregnancy. The only consistent item to appear on the PPE form was pertaining to time between menstrual cycles (62.5\%) and it appeared on the community college PPE form. The PPE forms for the high school and community college had few items pertaining to onset of menarche ( $15 \%$ and $12.5 \%$ respectively), or most recent menstrual cycle ( $15 \%$ and $37.5 \%)$. Both the high schools and community colleges had 0 of the item in the category pertaining to immunizations.

High school PPE forms had 0 of $2(0 \%)$ items at/or above 50 percent compared to 2 of $2(100 \%)$ items at/or above 50 percent for items pertaining to environmental problems (see Table 1). High schools had few PPE forms that addressed the items of heat illness (46\%) and asthma (19\%), whereas the community college PPE forms consistently had items about these items ( $75 \%$ for both).

Some of the items found on the PPE forms that were not mentioned in the PPE Data Sheet were athlete's personal physician, insurance and policy number information, 
athlete's birthday, and the athlete's signature. The PPE Data Sheet did not measure items about dizziness during exercise, viral infections, diabetes, hernias, hospital preference, or previous illnesses. Items regarding drinking, smoking, tobacco use, hearing problems, urinary tract infections and breast discharge for females, or $\mathrm{x}$-rays were also not measured by the PPE Data Sheet, but were present on some of the PPE forms.

\section{Summary}

The sample consisted of 42 high schools and 11 community colleges from the Bay area. PPE forms were returned by 26 high schools and 8 community colleges. The raw data can be found in Appendix F. The high schools had only one category in which over 50 percent of the participating schools asked items and that was the demographic information category (56\%). Three categories (gynecological items, immunizations, and environmental) had items appear in less than $50 \%$ of the PPE forms that were returned. The majority of the percentages were from $0 \%$ to $38 \%$ for the items in the categories of gynecological questions, immunizations, and environmental issues with the highest percentage at $46 \%$ regarding the item about heat illness. Four categories (cardiac abnormality, head injury/neurological problems, medications, and orthopaedic/previous injuries) had percentages ranging from $19 \%$ to $46 \%$ for a majority of the items in each category.

Community colleges had 5 of the 8 categories (demographic information, cardiac abnormality, medications, orthopaedic/previous injuries, environmental) with percentages at/or over 50 percent. Three categories (head injury/neurological problems, gynecological items, and immunizations) had percentages ranging from $0 \%$ to $40 \%$ for a 
majority of the items in that particular category. Overall, the percentages for the community colleges were higher than the percentages for the high schools. The returned high school PPE forms had percentages at/or above 50 percent in 14 of the $44(32 \%)$ items, whereas the community colleges had 25 of the $44(57 \%)$ items at/or above 50 percent. Generally the high schoois and community colleges reported that an athlete should have a physical at least once a year prior to participating in sport on the PPE survey. 


\section{Chapter 5}

\section{DISCUSSION AND CONCLUSION}

The purpose of this study was to descriptively analyze various preparticipation physical evaluation (PPE) forms used in high schools and community colleges used to evaluate students' health risk prior to athletic participation. High school and community college athletic directors were asked to return a copy of the PPE form used at their school and answer a short survey. PPE forms that were collected were evaluated based on 44 criteria relating to items asked in the monograph PPE. Data were collected and coded on the PPE Data Sheet separately for high schools and community colleges. The total response rate for the high schools was 42 of $57(74 \%)$; however only 26 of $42(62 \%)$ returned a copy of the PPE form. The total response rate for the community colleges was 11 of $17(65 \%)$. Only 8 of $11(73 \%)$ returned a copy of their PPE form. In this chapter an analysis of the results is discussed and a comparison of the high school PPE forms to the community college PPE forms is made. Areas where PPE forms were deficient in measuring items is also be discussed.

\section{Discussion}

The analysis of PPE forms returned by community colleges illustrated that community colleges used more extensive PPE forms than high schools. PPE forms used in community colleges provide items in the categories about demographic information, cardiac abnormality, medications, orthopaedic/previous injuries, and environmental items. Community colleges were found to be lacking in items about head injury/neurological problems, gynecological issues, and immunizations. The high 
schools PPE forms were found to be lacking in asking items in all of the categories except the demographic items in which 9 of $16(56 \%)$ items were above $50 \%$.

Of the PPE forms analyzed from the high schools all categories lacked items except for the demographic category. In three of the categories (gynecological, immunizations, and environmental questions) the high school PPE forms addressed gynecological, immunization, and environmental item in less than $15 \%$ of the collected forms. The gynecological items were those pertaining to the last period, time between periods, and onset of menarche. There were no items about pregnancy. High school PPE forms covered the categories of cardiac abnormality, head injury/neurological problems, medications, and orthopaedic/previous injury $20 \%$ to $35 \%$ of the time. Johnson et al. (1993) placed importance on the medical history section and suggested that the medical history rivals the physical examination in importance and may potentially be more important. Koester (1995) also stated that an accurate history is essential in helping to determine that athlete's risk of physical harm.

Items about immunization ( $38 \%$ high school and $37.5 \%$ community college), pregnancy ( $0 \%$ for both), the onset of menarche (15\% high school and $12.5 \%$ community college), skin problems ( $23 \%$ high school and $25 \%$ community college), loss of a paired organ (31\% high school and $25 \%$ community college), and special equipment/corrective devices worn by the athlete ( $19 \%$ high school and $12.5 \%$ community college) were not found often on the PPE forms of the high schools and community colleges reviewed respectively. Few forms collected information about vitamin/supplement intake (15\% high school and $25 \%$ community college), numbness/tingling in the extremities (19\% 
high school and $12.5 \%$ community college), headaches (38\% high school and $37.5 \%$ community college), stingers/burners/pinched nerves ( $23 \%$ high school and $37.5 \%$ community college), and heart conditions denying participation (19\% high school and $0 \%$ community college). If items are not asked about numbness/tingling, headaches, stingers/burners/pinched nerves, and heart conditions the athlete may be at a greater risk of injury if they have a condition (past or present) that is not diagnosed and dealt with properly. An article titled Preseason Physical Examination in American Family Physician (1990) identified the main objective of the PPE as historical or physical conditions that could set up an athlete for injury. Rifat et al. (1995) suggested the PPE should be used to maintain the health and safety of the athletes during athletic competition. Fields and Delaney (1990) identified certain areas that should be covered in the PPE including cardiovascular risk, musculoskeletal injuries, and neurological injuries.

The high schools had items regarding age of the athlete (46\%), proof of exam (46\%), drug/supplement use ( $8 \%$ ), height (46\%), weight (46\%), blood pressure $(46 \%)$, and permission to treat in an emergency (46\%) appear in less than 50 percent of the PPE forms surveyed. Other items that appeared in less than 50 percent of the high school PPE forms were cardiac history ( $31 \%)$, heart murmurs $(23 \%)$, head injury/concussions $(46 \%)$, current medications ( $38 \%)$, previous injuries $(46 \%)$, female menstrual cycles $(15 \%)$ and pregnancy $(0 \%)$, heat illness ( $46 \%)$, and asthma $(19 \%)$.

Community colleges had items asking for information regarding age (37.5\%), grade level (25\%), emergency contacts (37.5\%), permission to treat in an emergency (25\%), and chest pain during exercise (37.5\%) in less than 50 percent of the PPE forms 
surveyed. According to Shrier (2001) he found that of 625 National Collegiate Athletic Association (NCAA) history and physical forms that were returned during a survey, only 163 forms had at least 9 of the 12 recommendations from the American Heart Association regarding screening guidelines for cardiovascular disease. He also noted that i50 of the 625 forms had 4 or less guidelines. Shrier also mentioned that improved cardiac screening would increase the finding of lesions associated with athlete's sudden death.

Both the high schools and community colleges surveyed were lacking is asking for permission to treat in an emergency. Prior consent to treat the athiete in an emergency according to Feinstein et al. (1988) gives authority to the coach, athletic trainer, or team physician to provide care to the injured athlete and decreases the liability when treating the athlete.

For the high school PPE forms, 12 of $26(46 \%)$, did not have any items beyond the demographic question category. All of the participating community colleges covered the categories of cardiac abnormalities and medications with consistency beyond the demographic category.

The items that appeared on the high school PPE forms with consistent frequency were sudden death of family member $(50 \%)$, seizures $(50 \%)$, allergies $(50 \%)$, previous surgeries $(50 \%)$, and hospital stays $(50 \%)$. The other items had a low frequency of appearing in the PPE form.

Beyond the demographic information the community colleges had the following items appear with consistent frequency: cardiac history $(62.5 \%)$, sudden death of family 
member $(50 \%)$, heart murmur $(62.5 \%)$, head injury/concussion $(87.5 \%)$, seizures $(50 \%)$, current medications (87.5\%), allergies (87.5\%), and vision (100\%). Other areas were strain/sprain/fracture/dislocation (87.5\%), previous injuries (87.5\%), previous surgeries (75\%), time between menstrual cycles $(62.5 \%)$, heat illness (75\%), and asthma (75\%). Matheson (1998) found in a study conducted by Bradford and Lyons (1991), that of the 114 public school districts surveyed in Pennsylvania $25 \%$ included no medical history and $60 \%$ did not have a musculoskeletal portion of the exam. Matheson also reported that Glover and Marion (1998) found that only $40 \%$ of the states had a questionnaire that covered a majority of the AHA recommendations for cardiac screening.

One of the items that may not be needed on the community college PPE form is parent/guardian signature. If an athlete is over $\mathbf{1 8}$ years old he or she is considered an adult and thus would not need the parent/guardian signature. It may be beneficial to include the parent/guardian signature based on the premise that with the signature the parent/guardian had reviewed the history section for accuracy.

A category that may not need to be addressed on either the high school or community college PPE form is immunizations. The reason being that the child or young adult needs to be immunized prior to being allowed into the school they are attending.

Conclusion

The data from this limited survey appear to show that the high schools and community colleges can improve the PPE form used. If 12 of 26 (46\%) PPE forms in the high schools do not ask questions beyond the demographic questions, not much 
information is given about the athlete to the athletic trainer and/or coach. The analysis of the data from the present study indicated that the high schools need major improvement in the areas of cardiac abnormalities, head injury/neurological problems, medications, orthopaedic/previous injuries, gynecological questions, immunizations and environmental issues.

Community colleges need to make adjustments to the currently used form. Some of the community colleges PPE forms were fairly extensive. The major changes to recommend to the community college PPE forms come in the areas of head injury/neurological problems, gynecological questions, and immunizations.

The eight variables that were evaluated in this study are like puzzle pieces, coupled with the physical examination. Each piece of the puzzle provides information, or a clue, to the health of the athlete. Without all of the pieces a complete picture is not possible and thus some vital information may be lost. If the picture of an athlete's health picture is not complete the results of not having all the information could be potentially fatal.

It is important to have as much demographic information on an athlete as possible so the information can be given to medical personnel in the event of an emergency. Emergency contact numbers should be available to the athletic trainer and coaching staff should a parent/guardian need to be contacted.

The cardiac abnormality and head injury/neurological problem categories are important to help diagnose potentially harmful conditions and identify preexisting conditions. With the information gained in these categories the athlete can be treated for 
any preexisting conditions and given advice on how to prevent further injury. According to the American Academy of Family Physicians et al. (1997) close attention should be paid to the cardiac history because over $95 \%$ of the sudden deaths of athletes under 30 years old are due to structural cardiac problems. According to Fields and Delaney (1990) neurological items are important because if neurological problems are uncovered a more in-depth history is needed. Fields and Delaney also mentioned that athletes with histories of concussions is placed into a special category where their participation clearance goes beyond the normal PPE.

The monograph from the American Academy of Family Physicians et al. (1997) mentioned it is important to obtain information about an athlete's allergies to medication. Certain precautions to make sure drugs are not given to the athlete accidentally and so proper emergency medication can be on hand for situations such as anaphylaxis should be taken.

According to Fields and Delaney (1990) items regarding orthpaedic/previous injuries are important because orthopaedic injuries help to direct the exam to attentively test a previously injured area. The items provide the opportunity to find out what type of rehabilitation an athlete has done for a previous injury should they reveal a history of orthopaedic problems. Fields and Delaney also mentioned that the risk of injuring a rehabilitated joint is significantly less when compared to the risk of reinjuring a joint with persistent weakness.

The American Academy of Family Physicians et al. (1997) stated that gynecological questions are important to help determine if a female athlete has primary 
or secondary amenorrhea. They found that poor nutrition, poor bone mineralization, and stress fractures might appear with exercise-associated amenorrhea.

According to the American Academy of Family Physician et al. (1997) immunization information is important so that the physician can see that the athlete is up to date on their immunizations. If the athlete is not up to date on their immunizations the physician can help plan an appointment for the booster shots.

Fields and Delaney (1990) suggested environmental issues are of importance to the PPE and that an athlete who has had one event of heat illness is at a higher risk of repeated problems. If an athlete responds that heat illness has been a problem, the physician can give the athlete some advice as to how to help prevent another incident. The American Academy of Family Physicians et al. (1997) also suggested that if the athlete is taking medications that may increase the risk of heat-related illness, the physician should determine if the medications might be discontinued during hotter months. Fluid replacement should be stressed to all athletes, but especially to those who have had a heat-related illness in the past.

Asthma is another environmental concern that is important to query about on the PPE. Fields and Delaney (1990) suggested the reason for asking a question about asthma is not to disqualify an athlete from competition but to initiate additional tests such as simple peak flow measurements. The PPE can identify the health matter and the athlete can be given treatment to participate more effectively. The recommendations of the American Academy of Family Physicians et al. (1997) are similar to Fields and Delaney 
(1990) that identifying athletes with asthma, or exercise-induced asthma (EIA), and providing treatment to them can allow them to participate and compete more efficiently.

\section{Recommendations for Further Study}

The following recommendations are made for further study of PPE forms in high schools and community colleges:

1. High schools and community colleges beyond a small geographic area in California should be surveyed to obtain a sense of how PPEs are used throughout the state.

2. Items regarding insurance and policy number, athlete's birthday, and athlete's signature should be added to the items measured under the demographic section of the variables checklist. Items about dizziness during exercise, viral infections, diabetes, hernias, hospital preference, previous illness, drinking, smoking, tobacco use, hearing problems, urinary tracts infections, breast discharge, and $\mathrm{x}$-rays should be added to the variables checklist to help gain a complete history of the athlete. An item about what kind of physician the athlete sees for their physical (M.D., D.O., D.C., N.P.) should be added to the variables checklist.

3. The role of the athletic trainer in the PPE should be examined. 


\section{References}

American Academy of Family Physicians, American Academy of Pediatrics, American Medical Society for Sports Medicine, American Orthopaedic Society for Sports Medicine, American Osteopathic Academy of Sports Medicine: Preparticipation Physicial Examination, ed 2, Minneapolis, New York City, McGraw-Hill, Inc, 1996.

Arnheim, D. D., \& Prentice, W. E. (2000). Principles of Athletic Training, $10^{\text {th }}$ Edition. Boston; McGraw-Hill Company.

Ball, R. M., (1991). The sports preparticipation evaluation. New Jersey Medicine, 88 , $629-633$.

Bradford, B.J., \& Lyons, C.W., (1991). Preparticipation sports assessment in western Pennsylvania. Journal of Adolescent Health, 12, 26 - 29.

Cantwell, J. D. (1998), Preparticipation physical evaluation: getting to the heart of the matter. Medicine and Science in Sports and Exercise, 30, S341-S344.

Carek, P. J., \& Futrell, M., (1999). Athletes' view of the preparticipation physical examination: Attitudes toward certain health screening question. Archives of Family Medicine, 8, 307-312. (From Journal of American Medical Association, 282: 1116k)

Carek, P. J., Futrell, M., \& Hueston, W. J., (1999). The preparticipation physical examination history: Who has the correct answers? Clinical Journal of Sport Medicine, 9, $124-128$.

Cavanaugh, Jr., R. M., Miller, M. L., \& Henneberger, P. K., ScD, MPH (1995). The preparticipation sports physical: Are we dropping the ball? Pediatrics, 96, 1151 1153.

Drezner, J. A. (2000). Sudden cardiac death in young athletes. Causes, athlete's heart, and screening guidelines. Postgraduate Medicine, 108, 37-50.

Dyment, P. G., (1992). The triple-threat sports exam. Patient Care, 26, 97-117.

Fields, K.B., (1994). Clearing athletes for participation in sport: The north carolina medical society sports medicine committee's recommended examination. North Carolina Medical Journal, 55, 116-120.

Fields, K. B., \& Delaney, M., (1990). Focusing the preparticipation sports examination. The Journal of Family Practice, 30, 304 -309. 
Feinstein, R. A., Soileau, E. J., \& Daniel, Jr., W. A., (1988). A national survey of preparticipation physical examination requirements. The Physician and Sports Medicine, 16, 51- 59.

Gallup, E. M., (1995). Law and the team physician. Champaign, IL; Human Kinetics.

Gemberling, C., (1996). Preparticipation Sports evaluation: An overview. Nurse Practitioner Forum. 7, 125-135.

Glover, D. W., \& Maron, B. J., (1998). Profile of preparticipation cardiovascular screening for high school athletes. Journal of American Medical Association. $279,1817-1819$.

Glover, D. W., Maron, B. J., \& Matheson, G. O., (1999). The preparticipation physical examination: Steps toward consensus and uniformity. The Physician and Sports Medicine, 27, 29-34.

Henderson, J. M., (1992). The preparticipation screening evaluation. Journal of Medical Association of Georgia, 81, 277 - 282.

Hoekelman, R. A., (1992). A pediatrician's view: The preparticipation sports physical examination. Pediatric Annals, 2I, 145 - 146.

Horgenroeder, A. C., (1997). The preparticipation sports examination. Pediatric Clinics of North America, H., 1525 - 1540.

Johnson, M. D., Kibler, W. B., \& Smith, D., (1993). Keys to successful preparticipation exams. The Physician and Sports Medicine, 21, $109-123$.

Koester, M. G., (1995). Refocusing the adolescent preparticipation physical evaluation toward preventive health care. Journal of Athletic Training, 30, 352 - 359.

Krowchuk, D. P., Krowchuk, H. V., Hunter, D. M., Zimet, G. D., Rainey, D. Y., Martin, D. F., \& Curl, W. W., (1995). Parents' knowledge of the purposes and content of preparticipation physical examinations. Archives of Pediatric and Adolescent Medicine, $149,653-657$.

Lyznicki, J. M., Nielsen, N. H., \& Schneider, J. E., (2000). Cardiovascular screening of student athletes. American Family Physician, 62, 765-774.

Magee, D. J., (1997). Orthopedic Physical Assessment, Third Edition. Philadelphia; W.B. Saunders Company 
Maron, B. J., Thompson, P. D., Puffer, J. C., McGrew, C. A., Strong, W. B., Douglas, P.S., Clark, L.T., Mitten, M.J., Crawford, M.H., Atkins, D.L., Driscoll, D.J., \& Epstein, A.E., (1996). Cardiovascular preparticipation screening of competitive athletes: A statement for health professionals from the sudden death committee (clinical cardiology) and congenital cardiac defects committee (cardivascular disease in the young), American Heart Association. Circulation, 9f, 850-856.

Matheson, G. O., (1998). Preparticipation screening of athletes. Journal of American Medical Association, 279, 1829-1830.

McKeag, D. B. (1985). Preseason physical examination for the prevention of sports injuries. Sports Medicine. 2, 413-431.

McKeag, D. B., \& Sallis, R. E., (2000). Factors at play in the athletic preparticipation examination. American Family Physician, 6I, 2617 - 2618.

Mellion, M.B., (1994). Sports Medicine Secrets. Philadelphia, PA: Hanley and Belfus, Inc.

Pfister, G.C., Puffer, J.C., \& Maron, B.J., (2000). Preparticipation cardiovascular screening for US collegiate student-athletes. Journal of American Medical Association, 283, $1597-1599$.

Rifat, S. F., Ruffin IV, M. T., \& Gorenflo, D. W., (1995). Disqualifying criteria in a preparticipation sports evaluation. The Journal of Family Practice, +l, $42-48$.

Samples, P. (1986). Preparticpation exams: Are they worth the time and trouble. The Physician and Sports Medicine, 1f, $180-187$.

Schnirring, L. (1999). High school association declines national ppe form. The Physician and Sports Medicine, 27, 25 - 26.

Shrier, I., (2001). College preparticipation cv disease screening often deficient. The Physician and Sportsmedicine, 29, 15.

Stedman's Medical Dictionary, $25^{\text {th }}$ edition (1990). Baltimore; Williams \& Wilkins.

Stenger, A., (1993). New preparticipation exam guidelines. The Physician and Sports Medicine, 2l, 14.

Strong, W. B., (1994). Preparticipation physical examination: It should be required. Archives of Pediatric and Adolescent Medicine, 1+8, 99 - 100. 
Tanji, J. L., (1990). The preparticipation physical examination for sports. American Family Physician, +2, $397-402$.

Tennant, Jr., F.S., Sorenson, K., \& Day, C. M., (1981). Benefits of preparticipation sports evaluations. The Journal of Family Practice, 13, 287-288.

Tucker, M. E. (1999). Sport physical doubles as comprehensive exam. Family Practice News, 29, 30.

Report of the Board of Trustees. (1994, January). Athletic preparticipation examinations for adolescents. Archives of Pediatric and Adolescent Medicine, 148, 93-98. American Medical Association, Chicago, Ill.: Author.

Preseason Physical Examinations. (1990, April). American Family Physician, +l, 1260.

Available from the Santa Clara County Office of Education at http://www.sccoe.org.

Available from the Fremont Union High School District at http://www.fuhsd.org.

Available from the Mountain View/Los Altos Union High School District at http://www.mvla.k12.ca.us.

Available from the East Side Union High School District at http://www.esuhsd.org.

Available from the Campbell Union High School District at http://www.cuhsd.org.

Available from the Los Gatos/Saratoga Union High School District at http://www.lgsuhsd.org. 
Appendix A

Letter to Athletic Directors 
San José State UNIVERSIT Y

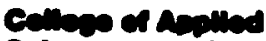
colonowe end arts

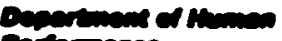
mencomeses

One Washington Squere Sen Jost. CA 95192.0054 vance: 400-824-3010

Fax: $408-924-3053$

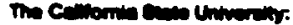

crenceloris Once

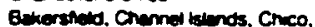
Dommonez Froeno, Fulerion. Honwerd. Mumbolit. Long Baner. Los Angewas. Martime Acsocemy.

Momerey Bey. Nortmodo. Pornons.

Secrenento. Sen Barnerino. Sen Depo. Sen Francesco. Sen toed. Sen Lues Obmoo. Sen Murcos. Sonome. Stensimes

\author{
(High School/Community College A.D.) \\ (High School/Community College) \\ (High School/Community College address) \\ (City, State) \\ (Zip code)
}

Matthew Smith

2035 Kings Lane

San Mateo, CA 94402

E-mail: MT8695@aol.com

Dear (High School/Community College A.D.):

My name is Matthew Smith and I am a graduate student at San Jose State University. I am currently working on my master's thesis project and am writing to ask you for your help. I am looking to analyze the medical history/physical form used by Bay Area educational institutions prior to an athlete participating in sport. I am also gathering information about the content of the preparticipation physical examination (PPE) form used in Bay Area high schools and community colleges. You can help by returning a copy of the form currently used at your institution. I provided a self-addressed stamped envelope. Your help is much appreciated. If you have any questions you may call me at 650-574-4211 or you may speak with my thesis committee chair Dr. Emily Wughalter at San Jose State University on her personal phone (408-924-3043) or e-mail (ewughalt@email.sjsu.edu).

If a preparticipation physical evaluation (PPE) form is not used in your school or college, please indicate what you use as proof that the athlete had a medical exam prior to participating in athletics. Please use the attached page to indicate what is required from the athlete/parent if a PPE form is not used. If a preparticipation physical evaluation (PPE) for is used, please use the attached page to indicate how often the evaluation is required at your school.

You should understand that your participation is voluntary and that choosing not to participate in this study, or in any part of this study, will not affect your relations with San Jose State University. No risks or benefits are anticipated by your participation in the research study.

The results of the study may be published, but any information that could result in your identification will remain confidential. If you choose to participate in the study please sign the bottom of the Preparticipation Physical Evaluation Survey. Any questions about research, subject's 
rights, or research-related injury may be directed to Nabil Ibrahim, Ph.D., Associate Vice President for Graduate Studies and Research, at (408) 924 -2480 .

By returning a PPE form and/or the PPE survey you imply your consent to participate in the research study.

Thank you in advance for your help and cooperation. I hope to hear from you soon.

Sincerely,

Matthew Smith, Graduate Athletic Trainer 
Appendix B

Preparticipation Physical Evaluation Survey 


\section{Pre-Participation Physical Evaluation Survey}

What is required from the athlete if a preparticipation physical evaluation (PPE) form is not used at your educational institution? (Please check one answer below and/or provide an explanation as to what is required by your student athletes) If a PPE form is not used at your educational institution please note under the comment section as to what the parents/child are required to submit prior to the student participating in sports.

A physician's note

No note is required

A note from the athlete's parents

Other (please explain below)

Comments:

If a preparticipation physical evaluation is required prior to the athlete participating in sport, how often is the evaluation required? (Please check an answer below)

Once a year

Every two years

Every three years

Prior to each sport the athlete wishes to participate in

Other (please explain below) 


\section{Appendix C}

\section{Variables Checklist}


PPE DATA SHEET

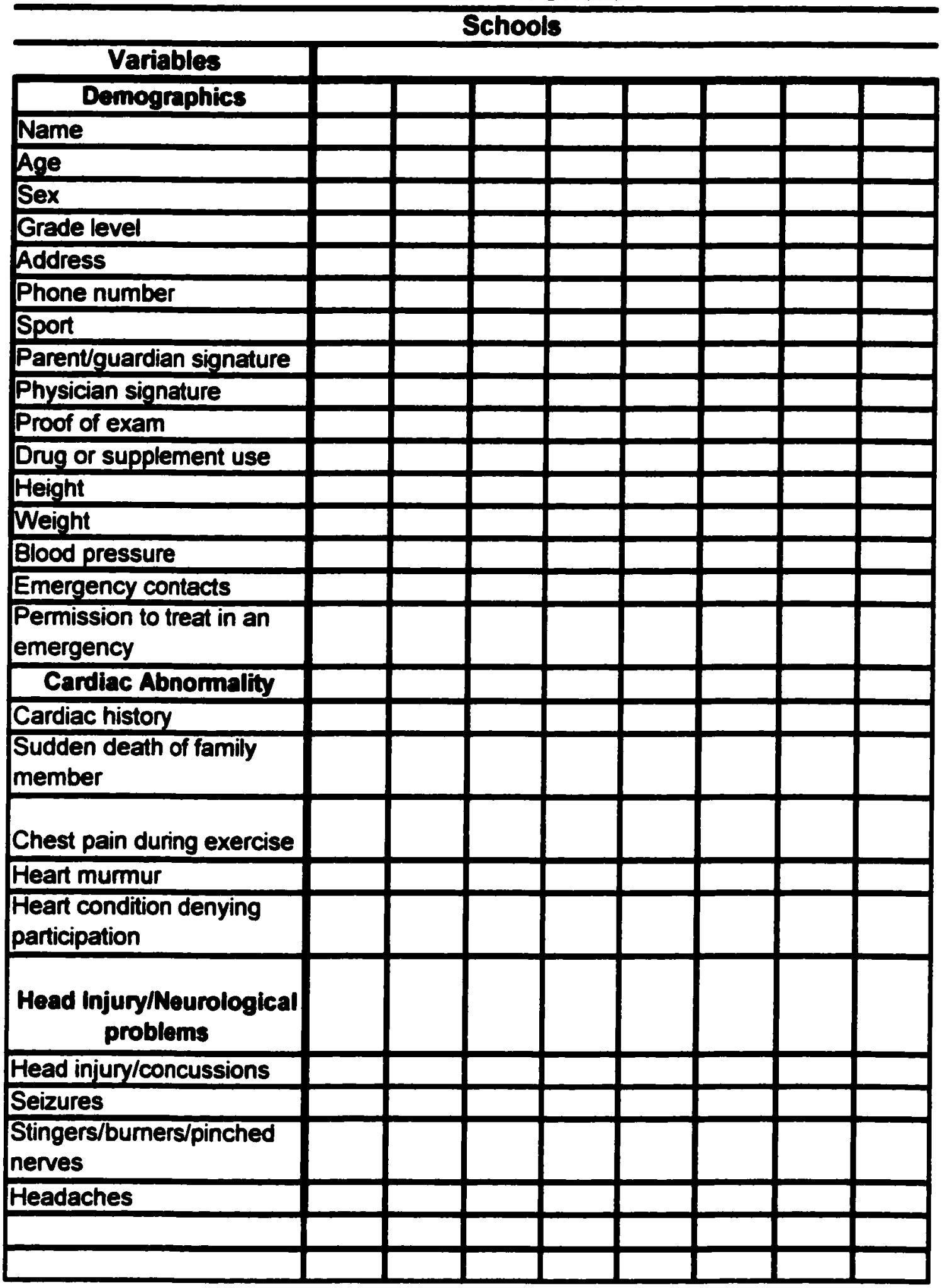


PPE DATA SHEET

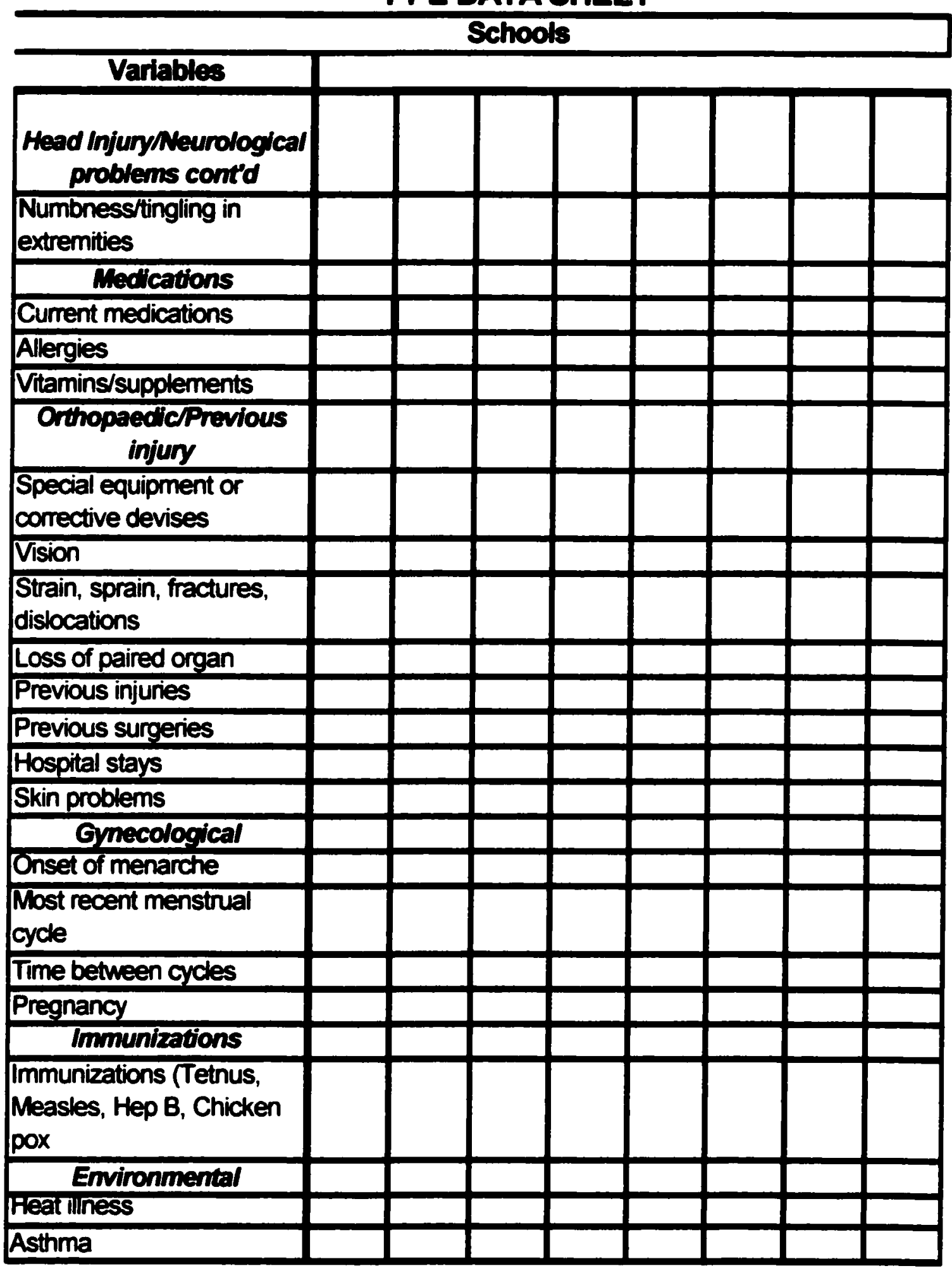


Appendix D

Follow-up Letter 


\section{San José State}

\section{UNIVERSITY}
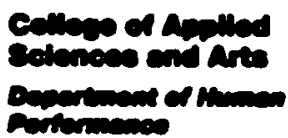

One Washnoton Square Sen Jose. CA 95192.0054 Vowce: 408-924-3010

Fax: $400-924-3053$
Matthew Smith 2035 Kings Lane

San Mateo, CA 94402

Email: MT8695@aol.com

(High School/Community College A.D.)

(High School/Community College)

(High School/Community College address)

(City, State)

(Zip code)

Dear (High School/Community College A.D.):

A few weeks ago I sent a letter to you requesting your help in collecting the PPE form that is used in your school and your responses to a short survey regarding the content of the PPE form. As of yet I have not received your response. If you have already mailed your response please disregard this letter. If you have not mailed your response please do so in the next couple of days.

Your help is greatly appreciated. Thank you for your assistance and I hope to hear from you soon. If you have any further questions please call me at 650-574-4211 or Dr. Emily Wughaiter at 408-924-3043.

Sincerely,

Matthew Smith, Graduate Athletic Trainer 


\section{Appendix E}

\section{Variables Checklist with Data}




\begin{tabular}{|c|c|c|c|c|c|c|c|c|c|c|c|c|}
\hline & & & & \multicolumn{5}{|c|}{ PPE DATA SHEET } & & \multirow[b]{3}{*}{26} & \multirow[b]{3}{*}{27} & \multirow[b]{3}{*}{29} \\
\hline & & & & & & 100 & & & \multirow[b]{2}{*}{25} & & & \\
\hline VARIABLES & 1 & 3 & 8 & 11 & 12 & 15 & 21 & 23 & & & & \\
\hline \multicolumn{13}{|l|}{ Demographics } \\
\hline Name & 1 & 1 & 1 & 1 & 1 & 1 & 1 & 1 & 1 & 1 & 1 & 1 \\
\hline Age & 1 & 0 & 1 & 1 & 0 & 0 & 0 & 0 & 1 & 1 & 0 & 0 \\
\hline Sex & 0 & 0 & 0 & 1 & 0 & 1 & 0 & 0 & 1 & $\overline{1}$ & 1 & 0 \\
\hline Grade level & 1 & 1 & 0 & 1 & 0 & 0 & 1 & 1 & 1 & 1 & 0 & 0 \\
\hline Address & 1 & 1 & 0 & 1 & 1 & 1 & 1 & 1 & 0 & 1 & 0 & 0 \\
\hline Phone number & 1 & 1 & 0 & 1 & 1 & 1 & 1 & 1 & 0 & 1 & 0 & 1 \\
\hline Sport & 1 & 1 & 1 & 1 & 0 & 1 & 0 & 1 & 1 & 1 & 0 & 0 \\
\hline Parent/guardian signature & 1 & 1 & 1 & 1 & 1 & 1 & 1 & 1 & 0 & 1 & 1 & 1 \\
\hline Physician signature & 1 & 1 & 1 & 1 & 1 & 1 & 1 & 1 & 1 & 1 & 1 & 1 \\
\hline Proof of exam & 1 & 0 & 0 & 1 & 0 & 1 & 0 & 0 & 1 & 1 & 0 & 0 \\
\hline Drug or supplement use & 0 & 0 & 0 & 1 & 0 & 0 & 0 & 0 & 1 & 0 & 0 & 0 \\
\hline Height & 1 & 0 & 0 & 1 & 0 & 1 & 0 & 0 & 1 & 1 & 0 & 0 \\
\hline Weight & 1 & 0 & 0 & 1 & 0 & 1 & 0 & 0 & 1 & 1 & 0 & 0 \\
\hline Blood pressure & 1 & 0 & 0 & 1 & 0 & 1 & 0 & 0 & 1 & 1 & 0 & 0 \\
\hline Emergency contacts & 1 & 1 & 0 & 1 & 0 & 1 & 0 & 0 & 0 & 0 & 0 & 0 \\
\hline $\begin{array}{l}\text { Permission to treat in an } \\
\text { emergency }\end{array}$ & 1 & 0 & 1 & 1 & 0 & 1 & 1 & 0 & 0 & 0 & 1 & 0 \\
\hline \multicolumn{13}{|l|}{ Cardiac Abnormality } \\
\hline Cardiac history & 1 & 0 & 1 & 1 & 0 & 1 & 0 & 0 & 1 & 0 & 0 & 0 \\
\hline $\begin{array}{l}\text { Sudden death of family } \\
\text { member }\end{array}$ & 1 & 0 & 1 & 1 & 0 & 1 & 0 & 0 & 1 & 1 & 0 & 0 \\
\hline Chest pain during exercise & 1 & 0 & 0 & 1 & 0 & 1 & 0 & 0 & 1 & 1 & 0 & 0 \\
\hline Heart murmur & 0 & 0 & 0 & 1 & 0 & 0 & 0 & 0 & 1 & 1 & 0 & 0 \\
\hline $\begin{array}{l}\text { Heart condition denying } \\
\text { pariticipation }\end{array}$ & 0 & 0 & 0 & 1 & 0 & 0 & 0 & 0 & 1 & 0 & 0 & 0 \\
\hline \multicolumn{13}{|l|}{$\begin{array}{c}\text { Head Injury I Neurological } \\
\text { problems }\end{array}$} \\
\hline Head injury/concussions & 1 & 0 & 0 & 1 & 0 & 1 & 0 & 0 & 1 & 1 & 0 & 0 \\
\hline Seizures & 1 & 0 & 1 & 1 & 0 & 1 & 0 & 0 & 1 & 1 & 0 & 0 \\
\hline $\begin{array}{l}\text { Stingers/burners/pinched } \\
\text { nerves }\end{array}$ & 0 & 0 & 0 & 1 & 0 & 0 & 0 & 0 & 1 & 1 & 0 & 0 \\
\hline Headaches & 0 & 0 & 0 & 1 & 0 & 1 & 0 & 0 & 1 & 0 & 0 & 0 \\
\hline $\begin{array}{l}\text { Numbness/tingling in } \\
\text { extremities }\end{array}$ & 0 & 0 & 0 & 1 & 0 & 0 & 0 & 0 & 1 & 0 & 0 & 0 \\
\hline \multicolumn{13}{|l|}{ Medications } \\
\hline Current medications & 1 & 0 & 1 & 1 & 0 & 1 & 0 & 0 & 1 & 0 & 0 & 0 \\
\hline Allergies & 1 & 0 & 0 & 1 & 0 & 1 & 0 & 0 & 1 & 1 & 0 & 0 \\
\hline Vitamins/supplements & 0 & 0 & 0 & 1 & 0 & 0 & 0 & 0 & 0 & 0 & 0 & 0 \\
\hline & & & & & & & & & & & & \\
\hline & & & & & & & & & & & & \\
\hline & & & & & & & & & & & & \\
\hline & & & & & & & & & & & & \\
\hline
\end{tabular}




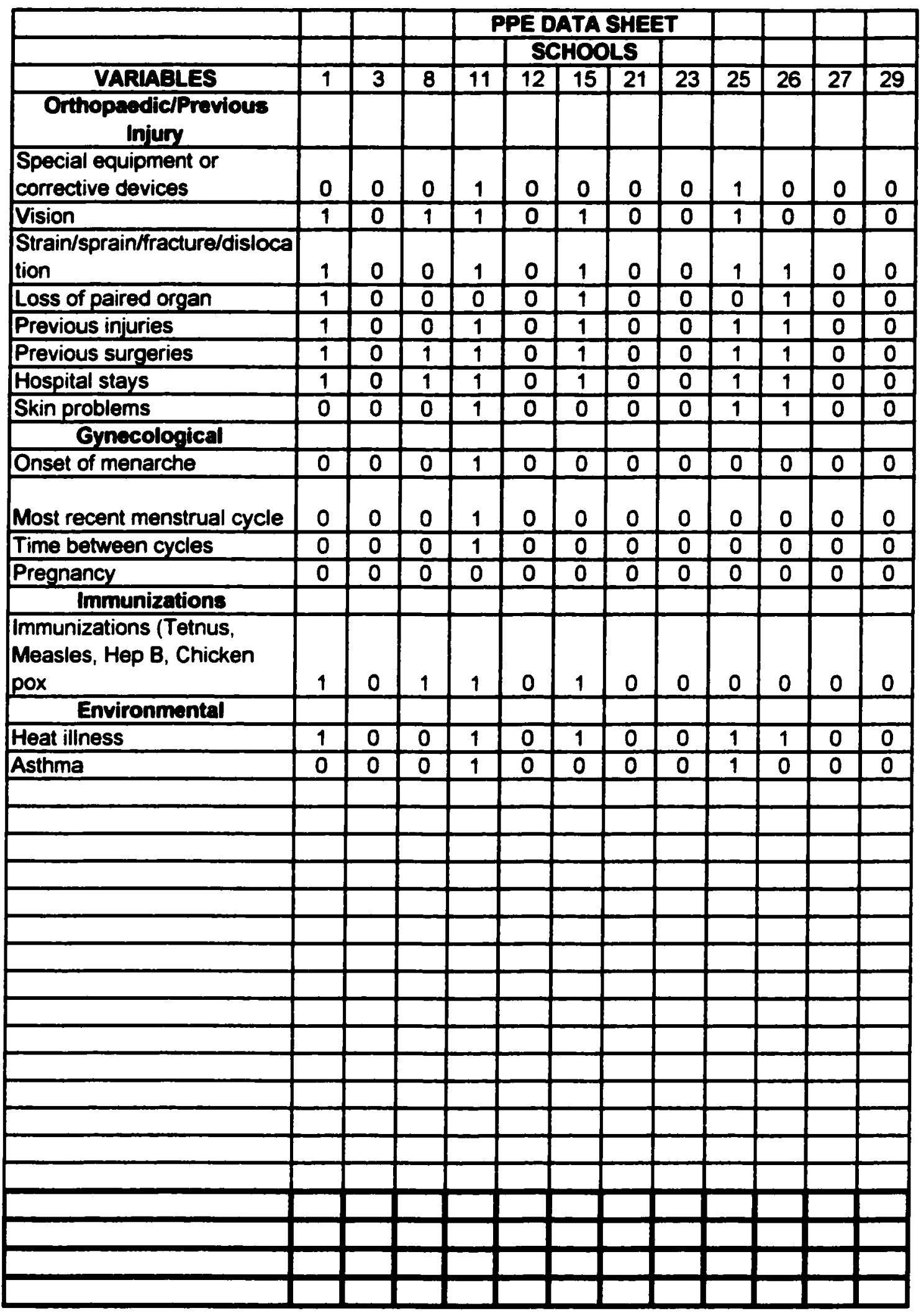




\begin{tabular}{|c|c|c|c|c|c|c|c|c|c|c|c|c|}
\hline & & & & \multicolumn{5}{|c|}{ PPE DATA SHEET } & & & \multirow[b]{3}{*}{4} & \multirow[b]{3}{*}{16} \\
\hline & & & & & & 100 & & & & & & \\
\hline VARIABLES & 36 & 39 & 40 & 41 & 42 & 43 & 44 & 47 & 53 & 2 & & \\
\hline \multicolumn{13}{|l|}{ Demographics } \\
\hline Name & & 1 & 1 & 1 & 1 & 1 & 1 & 1 & 1 & 1 & & 1 \\
\hline Age & & 1 & 1 & 0 & 1 & 0 & 0 & 0 & 1 & 1 & & 0 \\
\hline Sex & & 1 & 0 & 0 & 1 & 1 & 0 & 0 & 1 & 1 & & 0 \\
\hline Grade level & & 1 & 1 & 1 & 1 & 1 & 1 & 0 & 1 & 1 & & 1 \\
\hline Address & & 1 & 1 & 1 & 1 & 1 & 1 & 1 & 1 & 1 & & 1 \\
\hline Phone number & & 1 & 1 & 0 & 1 & 1 & 1 & 1 & 1 & 1 & & 1 \\
\hline Sport & & 1 & 1 & 0 & 1 & 0 & 0 & 0 & 1 & 1 & & 0 \\
\hline Parent/guardian signature & & 1 & 1 & 1 & 1 & 1 & 1 & 1 & 1 & 1 & & 1 \\
\hline Physician signature & & 1 & 1 & 1 & 1 & 1 & 1 & 1 & 1 & 1 & & 1 \\
\hline Proof of exam & & 1 & 1 & 0 & 1 & 0 & 0 & 0 & 1 & 1 & & 0 \\
\hline Drug or supplement use & & 0 & 0 & 0 & 0 & 0 & 0 & 0 & 0 & 0 & & 0 \\
\hline Height & & 1 & 1 & 0 & 1 & 0 & 0 & 0 & 1 & 1 & & 0 \\
\hline Weight & & 1 & 1 & 0 & 1 & 0 & 0 & 0 & 1 & 1 & & 0 \\
\hline Blood pressure & & 1 & 1 & 0 & 1 & 0 & 0 & 0 & 1 & 1 & & 0 \\
\hline Emergency contacts & & 1 & 0 & 1 & 1 & 1 & 1 & 0 & 1 & 0 & & 1 \\
\hline $\begin{array}{l}\text { Permission to treat in an } \\
\text { emergency }\end{array}$ & & 0 & 0 & 1 & 0 & 1 & 0 & 0 & 1 & 0 & & 1 \\
\hline \multicolumn{13}{|l|}{ Cardiac Abnomality } \\
\hline Cardiac history & & 0 & 0 & 0 & 1 & 0 & 0 & 0 & 1 & 0 & & 0 \\
\hline $\begin{array}{l}\text { Sudden death of family } \\
\text { member }\end{array}$ & & 1 & 1 & 0 & 1 & 0 & 0 & 0 & 1 & 1 & & 0 \\
\hline Chest pain during exercise & & 1 & 1 & 0 & 1 & 0 & 0 & 0 & 1 & 1 & & 0 \\
\hline Heart murmur & & 0 & 0 & 0 & 1 & 0 & 0 & 0 & 1 & 0 & & 0 \\
\hline $\begin{array}{l}\text { Heart condition denying } \\
\text { pariticipation }\end{array}$ & & 0 & 0 & 0 & 1 & 0 & 0 & 0 & 1 & 0 & & 0 \\
\hline \multicolumn{13}{|l|}{$\begin{array}{c}\text { Head Injury I Neurological } \\
\text { problems }\end{array}$} \\
\hline Head injury/concussions & & 1 & 1 & 0 & 1 & 0 & 0 & 0 & 1 & 1 & & 0 \\
\hline Seizures & & 1 & 1 & 0 & 1 & 0 & 0 & 0 & 1 & 1 & & 0 \\
\hline $\begin{array}{l}\text { Stingers/burners/pinched } \\
\text { nerves }\end{array}$ & & 0 & 0 & 0 & 1 & 0 & 0 & 0 & 1 & 0 & & 0 \\
\hline Headaches & & 1 & 1 & 0 & 1 & 0 & 0 & 0 & 1 & 1 & & 0 \\
\hline $\begin{array}{l}\text { Numbness/tingling in } \\
\text { extremities }\end{array}$ & & 0 & 0 & 0 & 1 & 0 & 0 & 0 & 1 & 0 & & 0 \\
\hline \multicolumn{13}{|l|}{ Modications } \\
\hline Current medications & & 0 & 0 & 0 & 1 & 0 & 0 & 0 & 1 & 1 & & 0 \\
\hline Allergies & & 1 & 1 & 0 & 1 & 0 & 1 & 0 & 1 & 1 & & 0 \\
\hline Vitamins/supplements & & 0 & 0 & 0 & 1 & 0 & 0 & 0 & 1 & 0 & & 0 \\
\hline & & & & & & & & & & & & \\
\hline & & & & & & & & & & & & \\
\hline & & & & & & & & & & & & \\
\hline & & & & & & & & & & & & \\
\hline
\end{tabular}




\begin{tabular}{|c|c|c|c|c|c|c|c|c|c|c|c|c|}
\hline & & & & \multirow{2}{*}{\multicolumn{5}{|c|}{ PPE DATA SHEET }} & \multirow[b]{3}{*}{53} & \multirow[b]{3}{*}{2} & \multirow[b]{3}{*}{4} & \multirow[b]{3}{*}{16} \\
\hline & & & & & & & & & & & & \\
\hline VARIABLES & 36 & 39 & 40 & 41 & 42 & 43 & 44 & 47 & & & & \\
\hline $\begin{array}{l}\text { Orthopedic/Previous } \\
\text { Injury }\end{array}$ & & & & & & & & & & & & \\
\hline $\begin{array}{l}\text { Special equipment or } \\
\text { corrective devices }\end{array}$ & & 0 & 0 & 0 & 1 & 0 & 0 & 0 & 1 & 0 & & 0 \\
\hline Vision & & 1 & 1 & 0 & 1 & 0 & 0 & 0 & 1 & 1 & & 0 \\
\hline $\begin{array}{l}\text { Strain/sprain/fracture/disloca } \\
\text { tion }\end{array}$ & & 1 & 1 & 0 & 1 & 0 & 0 & 0 & 1 & 1 & & 0 \\
\hline Loss of paired organ & & 1 & 1 & 0 & 1 & 0 & 0 & 0 & 0 & 1 & & 0 \\
\hline Previous injuries & & 1 & 1 & 0 & 1 & 0 & 0 & 0 & 1 & 1 & & 0 \\
\hline Previous surgeries & & 1 & 1 & 0 & 1 & 0 & 0 & 0 & 1 & 1 & & 0 \\
\hline Hospital stays & & 1 & 1 & 0 & 1 & 0 & 0 & 0 & 1 & 1 & & 0 \\
\hline Skin problems & & 0 & 0 & 0 & 1 & 0 & 0 & 0 & 1 & 0 & & 0 \\
\hline Gynecolorical & & & & & & & & & & & & \\
\hline Onset of menarche & & 0 & 0 & 0 & 1 & 0 & 0 & 0 & 1 & 0 & & 0 \\
\hline Most recent menstrual cycle & & 0 & 0 & 0 & 1 & 0 & 0 & 0 & 1 & 0 & & 0 \\
\hline Time between cycles & & 0 & 0 & 0 & 1 & 0 & 0 & 0 & 1 & 0 & & 0 \\
\hline Pregnancy & & 0 & 0 & 0 & $\overline{0}$ & 0 & 0 & 0 & 0 & 0 & & 0 \\
\hline Immunizations & & & & & & & & & & & & \\
\hline $\begin{array}{l}\text { Immunizations (Tetnus, } \\
\text { Measles, Hep B, Chicken } \\
\text { pox }\end{array}$ & & 1 & 1 & 0 & 0 & 0 & 0 & 0 & 1 & 1 & & 0 \\
\hline Environmental & & & & & & & & & & & & \\
\hline Heat illness & & 1 & 1 & 0 & 1 & 0 & 0 & 0 & 1 & 1 & & 0 \\
\hline Asthma & & 0 & 0 & 0 & 1 & 0 & 0 & 0 & 1 & 0 & & 0 \\
\hline & & & & & & & & & & & & \\
\hline & & & & & & & & & & & & \\
\hline & & & & & & & & & & & & \\
\hline & & & & & & & & & & & & \\
\hline & & & & & & & & & & & & \\
\hline & & & & & & & & & & & & \\
\hline & & & & & & & & & & & & \\
\hline & & & & & & & & & & & & \\
\hline & & & & & & & & & & & & \\
\hline & & & & & & & & & & & & \\
\hline & & & & & & & & & & & & \\
\hline & & & & & & & & & & & & \\
\hline & & & & & & & & & & & & \\
\hline & & & & & & & & & & & & \\
\hline & & & & & & & & & & & & \\
\hline & & & & & & & & & & & & \\
\hline
\end{tabular}




\begin{tabular}{|c|c|c|c|c|c|c|c|c|c|c|c|c|}
\hline & & & & & ED & TAA & HEE & & & & & \\
\hline & & & & & & 100 & & & & & & \\
\hline VARIABLES & 45 & 50 & 54 & 56 & 48 & 5 & 7 & 28 & 46 & 32 & 35 & 10 \\
\hline Demographics & & & & & & & & & & & & \\
\hline Name & & & 1 & & & 1 & & & & & 1 & \\
\hline Age & & & 0 & & & 1 & & & & & 1 & \\
\hline Sex & & & 0 & & & 1 & & & & & 1 & \\
\hline Grade level & & & 1 & & & 1 & & & & & 1 & \\
\hline Address & & & 1 & & & 1 & & & & & 1 & \\
\hline Phone number & & & 1 & & & 1 & & & & & 1 & \\
\hline Sport & & & 0 & & & 1 & & & & & 1 & \\
\hline Parent/guardian signature & & & 1 & & & 1 & & & & & 1 & \\
\hline Physician signature & & & 1 & & & 1 & & & & & 1 & \\
\hline Proof of exam & & & 0 & & & 1 & & & & & 1 & \\
\hline Drug or supplement use & & & 0 & & & 0 & & & & & 0 & \\
\hline Height & & & 0 & & & 1 & & & & & 1 & \\
\hline Weight & & & 0 & & & 1 & & & & & 1 & \\
\hline Blood pressure & & & 0 & & & 1 & & & & & 1 & \\
\hline Emergency contacts & & & 1 & & & 1 & & & & & 0 & \\
\hline $\begin{array}{l}\text { Permission to treat in an } \\
\text { emergency }\end{array}$ & & & 1 & & & 0 & & & & & 0 & \\
\hline Cardiac Abnormality & & & & & & & & & & & & \\
\hline Cardiac history & & & 0 & & & 1 & & & & & 0 & \\
\hline $\begin{array}{l}\text { Sudden death of family } \\
\text { member }\end{array}$ & & & 0 & & & 1 & & & & & 1 & \\
\hline Chest pain during exercise & & & 0 & & & 1 & & & & & 1 & \\
\hline Heart murmur & & & 0 & & & 1 & & & & & 0 & \\
\hline $\begin{array}{l}\text { Heart condition denying } \\
\text { pariticipation }\end{array}$ & & & 0 & & & 1 & & & & & 0 & \\
\hline $\begin{array}{l}\text { Head Injury I Neurological } \\
\text { problems }\end{array}$ & & & & & & & & & & & & \\
\hline Head injury/concussions & & & 0 & & & 1 & & & & & $\overline{1}$ & \\
\hline Seizures & & & 0 & & & 1 & & & & & 1 & \\
\hline $\begin{array}{l}\text { Stingers/burners/pinched } \\
\text { nerves }\end{array}$ & & & 0 & & & 1 & & & & & 0 & \\
\hline Headaches & & & 0 & & & 1 & & & & & 1 & \\
\hline $\begin{array}{l}\text { Numbness/tingling in } \\
\text { extremities }\end{array}$ & & & 0 & & & 1 & & & & & 0 & \\
\hline Medications & & & & & & & & & & & & \\
\hline Current medications & & & 0 & & & 1 & & & & & 1 & \\
\hline Allergies & & & 0 & & & 1 & & & & & 1 & \\
\hline Vitamins/supplements & & & 0 & & & 1 & & & & & 0 & \\
\hline & & & & & & & & & & & & \\
\hline & & & & & & & & & & & & \\
\hline & & & & & & & & & & & & \\
\hline & & & & & & & & & & & & \\
\hline
\end{tabular}




\begin{tabular}{|c|c|c|c|c|c|c|c|c|c|c|c|c|}
\hline & & & & & $\overline{P E D}$ & $\overline{T A}$ & HEE & & & & & \\
\hline & & & & & & 400 & & & & & & \\
\hline VARLABLES & 45 & 50 & 54 & 56 & 48 & 5 & 7 & 28 & 46 & 32 & 35 & 10 \\
\hline $\begin{array}{l}\text { Orthopaedic/Previous } \\
\text { Injuny }\end{array}$ & & & & & & & & & & & & \\
\hline $\begin{array}{l}\text { Special equipment or } \\
\text { corrective devices }\end{array}$ & & & 0 & & & 1 & & & & & 0 & \\
\hline Vision & & & 0 & & & 1 & & & & & 1 & \\
\hline $\begin{array}{l}\text { Strain/sprain/fracture/disloca } \\
\text { tion }\end{array}$ & & & 0 & & & 1 & & & & & 1 & \\
\hline Loss of paired organ & & & 0 & & & 0 & & & & & 1 & \\
\hline Previous injuries & & & 0 & & & 1 & & . & & & 1 & \\
\hline Previous surgeries & & & 0 & & & 1 & & & & & 1 & \\
\hline Hospital stays & & & 0 & & & 1 & & & & & 1 & \\
\hline Skin problems & & & 0 & & & 1 & & & & & 0 & \\
\hline Gynecolorical & & & & & & & & & & & & \\
\hline Onset of menarche & & & 0 & & & 1 & & & & & 0 & \\
\hline Most recent menstrual cycle & & & 0 & & & 1 & & & & & 0 & \\
\hline Time between cycles & & & 0 & & & 1 & & & & & 0 & \\
\hline Pregnancy & & & 0 & & & 0 & & & & & 0 & \\
\hline Immunizations & & & & & & & & & & & & \\
\hline $\begin{array}{l}\text { Immunizations (Tetnus, } \\
\text { Measles, Hep B, Chicken } \\
\text { pox }\end{array}$ & & & 0 & & & 1 & & & & & 1 & \\
\hline Environmental & & & & & & & & & & & & \\
\hline Heat illness & & & 0 & & & 1 & & & & & 1 & \\
\hline Asthma & & & 0 & & & 1 & & & & & 0 & \\
\hline & & & & & & & & & & & & \\
\hline & & & & & & & & & & & & \\
\hline & & & & & & & & & & & & \\
\hline & & & & & & & & & & & & \\
\hline & & & & & & & & & & & & \\
\hline & & & & & & & & & & & & \\
\hline & & & & & & & & & & & & \\
\hline & & & & & & & & & & & & \\
\hline & & & & & & & & & & & & \\
\hline & & & & & & & & & & & & \\
\hline & & & & & & & & & & & & \\
\hline & & & & & & & & & & & & \\
\hline & & & & & & & & & & & & \\
\hline & & & & & & & & & & & & \\
\hline & & & & & & & & & & & & \\
\hline & & & & & & & & & & & & \\
\hline
\end{tabular}




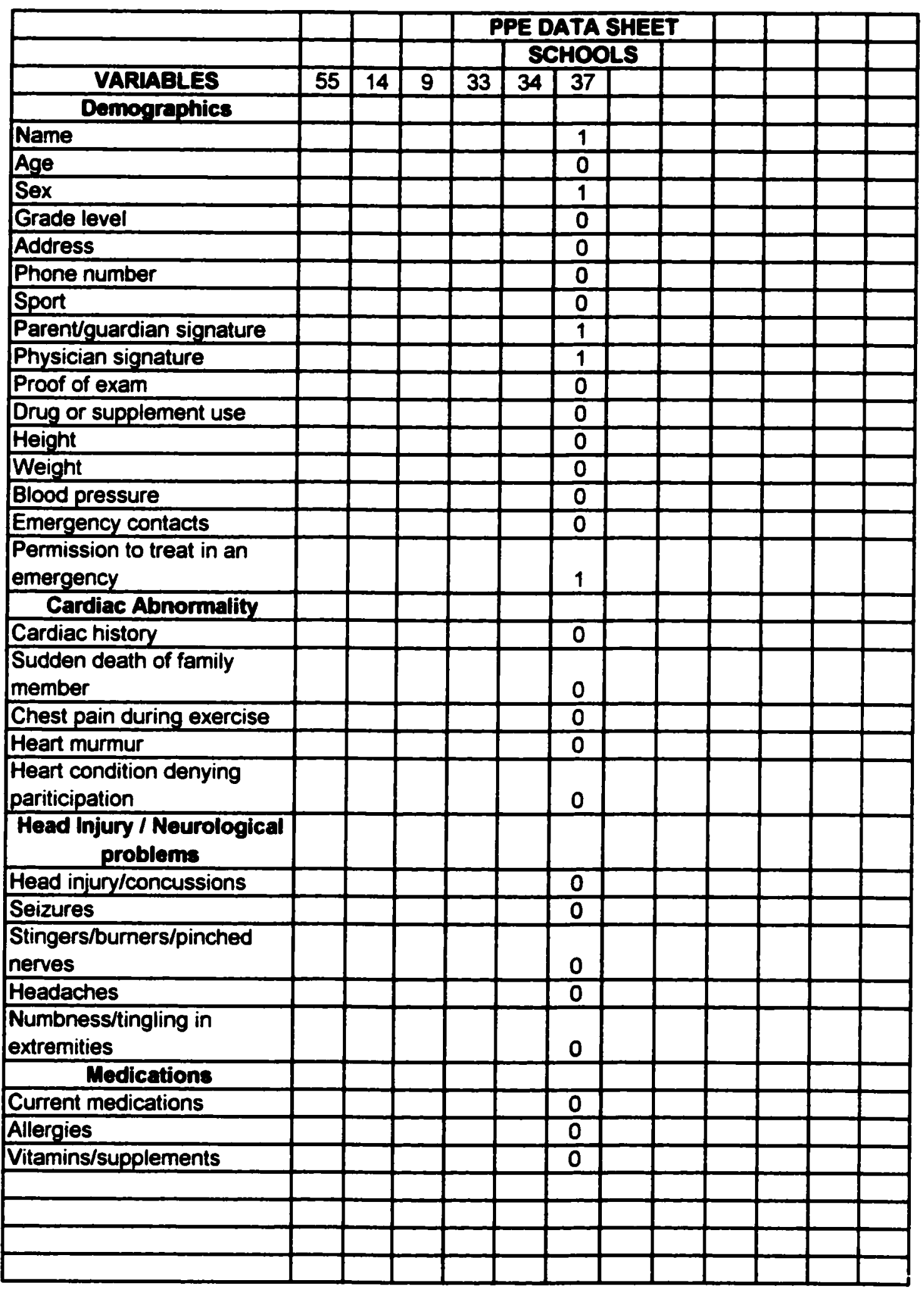




\begin{tabular}{|c|c|c|c|c|c|c|c|c|c|c|c|}
\hline & & & & \multirow{2}{*}{\multicolumn{5}{|c|}{$\begin{array}{l}\text { PPE DATA SHEET } \\
\text { SCHOOLS }\end{array}$}} & & & \\
\hline & & & & & & & & & & & \\
\hline VARIABLES & 55 & 14 & 9 & 33 & 34 & 37 & & & & & \\
\hline $\begin{array}{l}\text { Orthopedic/Provious } \\
\text { Injury }\end{array}$ & & & & & & & & & & & \\
\hline $\begin{array}{l}\text { Special equipment or } \\
\text { corrective devices }\end{array}$ & & & & & & 0 & & & & & \\
\hline Vision & & & & & & 0 & & & & & \\
\hline $\begin{array}{l}\text { Strain/sprain/fracture/disloca } \\
\text { tion }\end{array}$ & & & & & & 0 & & & & & \\
\hline Loss of paired organ & & & & & & 0 & & & & & \\
\hline Previous injuries & & & & & & 0 & & & & & \\
\hline Previous surgeries & & & & & & 0 & & & & & \\
\hline Hospital stays & & & & & & 0 & & & & & \\
\hline Skin problems & & & & & & 0 & & & & & \\
\hline Gynocological & & & & & & & & & & & \\
\hline Onset of menarche & & & & & & 0 & & & & & \\
\hline Most recent menstrual cycle & & & & & & 0 & & & & & \\
\hline Time between cycles & & & & & & 0 & & & & & \\
\hline Pregnancy & & & & & & 0 & & & & & \\
\hline Immunizations & & & & & & & & & & & \\
\hline $\begin{array}{l}\text { Immunizations (Tetnus, } \\
\text { Measles, Hep B, Chicken } \\
\text { pox }\end{array}$ & & & & & & 0 & & & & & \\
\hline Environmental & & & & & & & & & & & \\
\hline Heat illness & & & & & & 0 & & & & & \\
\hline Asthma & & & & & & 0 & & & & & \\
\hline & & & & & & & & & & & \\
\hline & & & & & & & & & & & \\
\hline & & & & & & & & & & & \\
\hline & & & & & & & & & & & \\
\hline & & & & & & & & & & & \\
\hline & & & & & & & & & & & \\
\hline & & & & & & & & & & & \\
\hline & & & & & & & & & & & \\
\hline & & & & & & & & & & & \\
\hline & & & & & & & & & & & \\
\hline & & & & & & & & & & & \\
\hline & & & & & & & & & & & \\
\hline & & & & & & & & & & & \\
\hline & & & & & & & & & & & \\
\hline & & & & & & & & & & & \\
\hline & & & & & & & & & & & \\
\hline
\end{tabular}




\begin{tabular}{|c|c|c|c|c|c|c|c|c|c|c|c|c|}
\hline & & & & \multicolumn{5}{|c|}{ PPE DATA SHEET } & & \multirow[b]{3}{*}{59} & \multirow[b]{3}{*}{67} & \\
\hline & & & & & & HOC & & & \multirow[b]{2}{*}{58} & & & \\
\hline VARIABLES & 60 & 63 & 64 & 66 & 68 & 72 & 73 & 65 & & & & \\
\hline \multicolumn{13}{|l|}{ Demographics } \\
\hline Name & & 1 & 1 & & 1 & 1 & 1 & 1 & 1 & & 1 & \\
\hline Age & & 1 & 1 & & 0 & 0 & 0 & 0 & 0 & & 1 & \\
\hline Sex & & 1 & 1 & & 1 & 1 & 1 & 1 & 0 & & 0 & \\
\hline Grade level & & 0 & 1 & & 0 & 0 & 0 & 0 & 0 & & 1 & \\
\hline Address & & 0 & 1 & & 1 & 1 & 0 & 1 & 0 & & 0 & \\
\hline Phone number & & 0 & 1 & & 1 & 1 & 0 & 1 & 0 & & 0 & \\
\hline Sport & & 1 & 1 & & 1 & 1 & 0 & 1 & 0 & & 1 & \\
\hline Parent/guardian signature & & 0 & 1 & & 0 & 1 & 0 & 0 & 0 & & 0 & \\
\hline Physician signature & & 1 & 1 & & 1 & 1 & 1 & 1 & 1 & & 1 & \\
\hline Proof of exam & & 1 & 1 & & 1 & 1 & 1 & 1 & 1 & & 1 & \\
\hline Drug or supplement use & & 1 & 0 & & 1 & 1 & 0 & 0 & 0 & & 1 & \\
\hline Height & & 1 & 1 & & 1 & 1 & 1 & 1 & 1 & & 1 & \\
\hline Weight & & 1 & 1 & & 1 & 1 & 1 & 1 & 1 & & 1 & \\
\hline Blood pressure & & 1 & 1 & & 1 & 1 & 1 & 1 & 1 & & 1 & \\
\hline Emergency contacts & & 0 & 1 & & 1 & 1 & 0 & 0 & 0 & & 0 & \\
\hline $\begin{array}{l}\text { Permission to treat in an } \\
\text { emergency }\end{array}$ & & 0 & 1 & & 0 & 0 & 1 & 0 & 0 & & 0 & \\
\hline \multicolumn{13}{|l|}{ Cardiac Abnormality } \\
\hline Cardiac history & & 0 & 1 & & 1 & 1 & 1 & 0 & 0 & & 1 & \\
\hline $\begin{array}{l}\text { Sudden death of family } \\
\text { member }\end{array}$ & & 1 & 0 & & 0 & 1 & 1 & 0 & 0 & & 1 & \\
\hline Chest pain during exercise & & 1 & 0 & & 0 & 1 & 1 & 0 & 0 & & 0 & \\
\hline Heart murmur & & 1 & 0 & & 0 & 1 & 1 & 1 & 1 & & 0 & \\
\hline $\begin{array}{l}\text { Heart condition denying } \\
\text { pariticipation }\end{array}$ & & 0 & 0 & & 0 & 0 & 0 & 0 & 0 & & 0 & \\
\hline \multicolumn{13}{|l|}{$\begin{array}{c}\text { Head Injury I Neurological } \\
\text { problems }\end{array}$} \\
\hline Head injury/concussions & & 1 & 1 & & 1 & 1 & 1 & 1 & 0 & & 1 & \\
\hline Seizures & & 0 & 1 & & 0 & 1 & 1 & 1 & 0 & & 0 & \\
\hline $\begin{array}{l}\text { Stingers/burners/pinched } \\
\text { nerves }\end{array}$ & & 1 & 1 & & 0 & 1 & 0 & 0 & 0 & & 0 & \\
\hline Headaches & & 0 & 0 & & 1 & 1 & 0 & 1 & 0 & & 0 & \\
\hline $\begin{array}{l}\text { Numbness/tingling in } \\
\text { extremities }\end{array}$ & & 0 & 0 & & 0 & 1 & 0 & 0 & 0 & & 0 & \\
\hline \multicolumn{13}{|l|}{ Medications } \\
\hline Current medications & & 1 & 1 & & 1 & 1 & 1 & 1 & 0 & & 1 & \\
\hline Allergies & & 1 & 1 & & 1 & 1 & 1 & 1 & 0 & & 1 & \\
\hline Vitamins/supplements & & 1 & 0 & & 0 & 1 & 0 & 0 & 0 & & 0 & \\
\hline & & & & & & & & & & & & \\
\hline & & & & & & & & & & & & \\
\hline & & & & & & & & & & & & \\
\hline & & & & & & & & & & & & \\
\hline
\end{tabular}




\begin{tabular}{|c|c|c|c|c|c|c|c|c|c|c|c|c|}
\hline & & & & \multicolumn{5}{|c|}{ PPE DATA SHEET } & & & \multirow[b]{3}{*}{67} & \\
\hline & & & & & & $\overline{\mathrm{HOO}}$ & & & & & & \\
\hline VARLABLES & 60 & 63 & 64 & 66 & 68 & 72 & 73 & 65 & 58 & 59 & & \\
\hline \multicolumn{13}{|l|}{$\begin{array}{l}\text { Orthopaedic/Previous } \\
\text { Injury }\end{array}$} \\
\hline $\begin{array}{l}\text { Special equipment or } \\
\text { corrective devices }\end{array}$ & & 1 & 0 & & 0 & 0 & 0 & 0 & 0 & & 0 & \\
\hline Vision & & 1 & 1 & & 1 & 1 & 1 & 1 & 1 & & 1 & \\
\hline $\begin{array}{l}\text { Strain/sprainffracture/disloca } \\
\text { tion }\end{array}$ & & 1 & 1 & & 1 & 1 & 1 & 1 & 0 & & 1 & \\
\hline Loss of paired organ & & 0 & 1 & & 0 & 0 & 0 & 0 & 0 & & 1 & \\
\hline Previous injuries & & 1 & 1 & & 1 & 1 & 1 & 1 & 0 & & 1 & \\
\hline Previous surgeries & & 1 & 1 & & 1 & 1 & 1 & 1 & 0 & & 0 & \\
\hline Hospital stays & & 1 & 0 & & 0 & 1 & 0 & 1 & 0 & & 0 & \\
\hline Skin problems & & 1 & 0 & & 0 & 0 & 1 & 0 & 0 & & 0 & \\
\hline \multicolumn{13}{|l|}{ Gynecological } \\
\hline Onset of menarche & & 0 & 0 & & 0 & 1 & 0 & 0 & 0 & & 0 & \\
\hline Most recent menstrual cycle & & 1 & 0 & & 0 & 1 & 0 & 0 & 0 & & 1 & \\
\hline Time between cycles & & 1 & 1 & & 1 & 1 & 1 & 0 & 0 & & 0 & \\
\hline Pregnancy & & 0 & 0 & & 0 & 0 & 0 & 0 & 0 & & 0 & \\
\hline \multicolumn{13}{|l|}{ Immunizations } \\
\hline $\begin{array}{l}\text { Immunizations (Tetnus, } \\
\text { Measles, Hep B, Chicken } \\
\text { pox }\end{array}$ & & 0 & 0 & & 0 & 1 & 0 & 1 & 0 & & 1 & \\
\hline \multicolumn{13}{|l|}{ Environmental } \\
\hline Heat illness & & 1 & 1 & & 1 & 1 & 1 & 0 & 0 & & 1 & \\
\hline Asthma & & 0 & 1 & & 1 & 1 & 1 & 1 & 0 & & 1 & \\
\hline & & & & & & & & & & & & \\
\hline & & & & & & & & & & & & \\
\hline & & & & & & & & & & & & \\
\hline & & & & & & & & & & & & \\
\hline & & & & & & & & & & & & \\
\hline & & & & & & & & & & & & \\
\hline & & & & & & & & & & & & \\
\hline & & & & & & & & & & & & \\
\hline & & & & & & & & & & & & \\
\hline & & & & & & & & & & & & \\
\hline & & & & & & & & & & & & \\
\hline & & & & & & & & & & & & \\
\hline & & & & & & & & & & & & \\
\hline & & & & & & & & & & & & \\
\hline & & & & & & & & & & & & \\
\hline & & & & & & & & & & & & \\
\hline & & & & & & & & & & & & \\
\hline
\end{tabular}




\section{Appendix F}

Synthesis of Data 
The following information is provided as a synthesis of the data collected on preparticipation physical evaluation (PPE) forms used in Santa Clara County high schools and San Francisco Bay area community colleges. The information below lists the items that were asked most often and least often on the PPE forms that were received. To fall under the most often asked items a variable had to be present in at least $50 \%$ of the PPE forms received for the high schools and community colleges surveyed. The items are first listed by category for high schools and then community colleges.

Demographic Information

The items most often asked on the high school PPE forms were name, sex, grade level, address, phone number, sport, parent/guardian signature, physician signature, and emergency contact.

The items asked least often on the high school PPE forms were age, proof of exam, drug/supplement use, height, weight, blood pressure, and permission to treat in an emergency.

Cardiac Abnormality

The item most often asked on the high school PPE forms was sudden death of a family member.

The items asked least often on the high school PPE forms were those about cardiac history, chest pain during exercise, heart murmur, and heart condition denying participation. 
Head Injury Neurological Problems

The item most often asked on the high school PPE forms was about seizures.

The items asked least often on the high school PPE forms were about head injury/concussion, stingers/burners/pinched nerves, headaches, and numbness/tingling in extremities.

\section{Medications}

The item most often asked on the high school PPE forms was concerning allergies.

The items asked least often on the high school PPE forms were about current medication and vitamin/supplement use.

Orthopaedic Previous Injury

The items most often asked on the high school PPE forms were about previous surgeries and hospital stays.

The items asked least often on the high school PPE forms were about special equipment/corrective devices, vision, sprain/strain/fracture/dislocation, loss of a paired organ, previous injury, and skin problems.

Gynecological

Very few of the high school PPE forms had items concerning gynecological information.

The items asked least often on the high school PPE forms were about onset of menarche, most recent menstrual cycle, time between cycles, and pregnancy. 


\section{Immunizations}

The items asked least often on the high school PPE forms was concerning immunizations (i.e., tetanus, measles, hepititis $B$, and chicken pox).

\section{Environmental}

The items asked least often on the high school PPE forms were about heat illness and asthma.

The following information pertains to the collected PPE forms from the community colleges.

\section{Demographic Information}

The items most often asked on the community college PPE forms were name, sex, address, phone number, sport, physician signature, proof of exam, drug/supplement use, height, weight, and blood pressure.

The items asked least often on the community college PPE forms were concerning age, grade level, parent/guardian signature, emergency contact, and permission to treat in an emergency.

Curdiac Abnormulity

The item most often asked on the community college PPE forms were sudden death of a family member, cardiac history, and heart murmur.

The items asked least often on the community college PPE forms were those about chest pain during exercise and any heart condition denying participation. 


\section{Head Injury Neurological Problems}

The items most often asked on the community college PPE forms were concerning seizures and head injury/concussion.

The items asked least often on the community college PPE forms were about stingers/burners/pinched nerves, headaches, and numbness/tingling in extremities.

\section{Medications}

The items most often asked on the community college PPE forms were about allergies and current medications.

The item asked least often on the community college PPE forms was about vitamin/supplement use.

Orthopaedic Previous Injury

The items most often asked on the community college PPE forms were about vision, sprain/strain/fracture/dislocation, previous injury, and previous surgeries.

The items asked least often on the community college PPE forms were about special equipment/corrective devices, loss of a paired organ, hospital stays, and skin problems.

Gynecological

The item most often asked on the community college PPE forms was regarding time between menstrual cycles.

The items asked least often on the community college PPE forms were concerning onset of menarche, most recent menstrual cycle, and pregnancy. 


\section{Immunizations}

The item asked least often on the community college PPE forms was concerning immunizations (i.e., tetanus, measles, hepititis B, and chicken pox).

Environmental

The items most often asked on the community college PPE forms were concerning heat illness and asthma.

The table below will show the variables that were checked against the PPE forms that were returned during the study. Next to the variable is a percentage representing how often that variable appeared in the returned PPE forms for high school and community college. Next to the listing of high school and community college will be a number in parentheses that represents the number of PPE forms that were returned. Any variable that listed over $50 \%$ of the time was considered good for this study. The percentages can be used to compare the PPE forms that are used at the high school or community college level to the PPE form that is currently used at your institution. The information can be used to update or revise the current PPE form, used at your institution, to contain questions in the areas in which your PPE form may be lacking or deficient. Demographic Information

Variable

Name

Age

Sex

Grade level Address

Phone number

Sport

Parent/guardian signature
High School $(n=26)$

Community College $(n=8)$

100

46

50

73

81

81

58

96
100

37.5

75

25

50

50

75

25 
Demographic Information continued

Physician signature

Proof of exam

Drug/supplement use

Height

Weight

Blood pressure

Emergency contact

Permission to treat in emergency
100

46

8

46

46

46

50

46
100

100

50

100

100

100

37.5

25

\section{Cardiac Abnormality}

Cardiac history

Sudden death of a family member

Chest pain during exercise

Heart murmur

Heart condition denying participation

Head Injury/Neurological Problems

Head injury/concussion

Seizures

Stingers/burners/pinched nerves

Headaches

Numbness/tingling in extremities
46

50

23

38

19
87.5

50

37.5

37.5

12.5

Medications

Current medications

38

87.5

Allergies

50

Vitamins/supplements

15

87.5

25

Orthopaedic/Previous Injuries

Special equipment or corrective devices 
Orthopaedic/Previous Injuries continued

\begin{tabular}{lll}
$\begin{array}{l}\text { Vision } \\
\text { Sprain/strain/fracture/ }\end{array}$ & 46 & 100 \\
$\quad$ dislocation & 46 & 87.5 \\
$\begin{array}{l}\text { Loss of paired organ } \\
\text { Previous injury }\end{array}$ & 31 & 25 \\
Previous surgeries & 46 & 87.5 \\
Hospital stays & 50 & 75 \\
Skin problems & 50 & 37.5 \\
\hline Gynecological & 23 & 25 \\
\hline $\begin{array}{l}\text { Onset of menarche } \\
\text { Most recent menstrual cycle }\end{array}$ & 15 & \\
Time between cycles & 15 & 12.5 \\
Pregnancy & 0 & 37.5 \\
\hline Immunizations & & 62.5 \\
\hline Immunizations (Tetanus, & & 0 \\
$\quad$ Measles, Hep B, Chicken pox) & 38 & 75 \\
\hline Environmental & & 76.5 \\
\hline Heat illness & 19 & \\
Asthma & & \\
\hline
\end{tabular}

Based on the table above there are some areas that could use some improvement on the high school and community college PPE forms. The high schools PPE forms appear to need more improvement than the community college forms. The following information is a list of the areas that need the most improvement on the respective PPE forms.

The areas in which the high school PPE form could be improved are questions concerning cardiac history, head injury/neurological problems, medications, 
orthopaedic/previous injury, gynecological information, immunizations, and environmental information.

The areas in which the community college PPE form could be improved are questions concerning head injury/neurological problems, gynecological information, and immunizations. 


\section{Appendix G}

\section{Approval Letter From San Jose State University Institutional Review Board (IRB)}


San José State

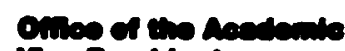

Vleo frealioment

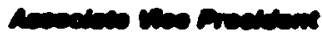

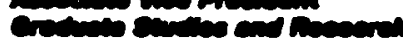

One Whehington Sques

Sen jose. CA $95192-0025$

Voice: $408-283-7500$

Fax: 400-924-2477

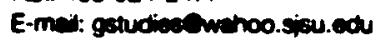

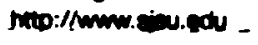

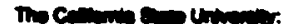

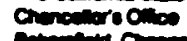

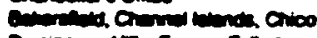

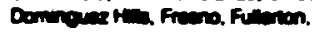

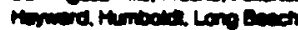

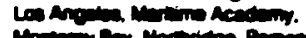

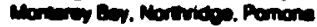

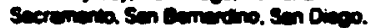

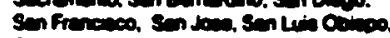

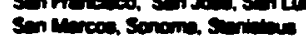

To: Mathew Smith 2035 Kings Lare Sen Mrteo, CA 94402

From: Nabil Torhim, N. EN D AVP, Gradute Surbes a Reverrch

Dace: Februmry 20, 2002

The Human Subjecte-Inatitutional Review Board has approved your requeat to use human subjects in the study entitled:

"Pro-Participation Evaluation Forms for High Schools and Community Colleges."

This approval is comingent upon the subjects perticipating in your research project being eppropriately protected from riak. This includes the protection of the anonymity of the subjects' identity when they participate in your research project, and with regard to any and all data that may be collected from the aubjects. The approval includes continued monitoring of your research by the Board to asaure that the aubjects are being adoquately and propenty protected from auch risks. If at any time a subject becomes injured or complains of injury, you must notify Nabil Ibrahim, Ph.D. immediately. Injury includes but is not limited to bodily harm, poychological trauma, and release of potentially damaging personal information. This spproval for the human subjects portion of your project is in efiect for one year, and dats collection beyond Febriary 19, 2003 requires an extension requeat.

Please also be advised that all aubjects need to be filly informed and aware that their participation in your research project is voluntary, and that he or she may withdraw from the project at any time. Further, a arbject's participation, refusal to participate, or withdrawal will not afiect any senvices that the aubject is receiving or will receive at the institution in which the research is being conducted.

If you have any questions, please contect me at (408) 9242480 . 